\title{
Zaman Esaslı Faaliyet Tabanlı Maliyetleme Yöntemi ile Konteyner Terminallerinde Maliyet Analizi ${ }^{*}$
}

\author{
R. Şebnem YAŞAR**
}

\section{ÖZET}

"Deniz taşımacıliğının sanayileşmesi" olarak da adlandırılan "konteyner taşımacılı̆̆ı", sunduğu çok sayıda teknik ve ekonomik avantajlardan dolayı dünya ticaretinde çok önemli bir yer edinmiş; buna bağlı olarak da konteyner terminallerinin önemi hızla artmıştır. Konteyner terminalleri arasındaki rekabet, maliyetleri azaltmak ve operasyonel verimliliği artırmak yönünde limanları baskı altına almaktadır. Maliyetlerin azaltılmasının ön koşulunu ise, doğru maliyet bilgisine sahip olmak oluşturmaktadır. Zaman Esasl Faaliyet Tabanlı Maliyetleme, geleneksel Faaliyet Tabanlı Maliyetleme metodolojisini temel alan, ancak daha basit ve daha az maliyetli alternatif bir sistem olarak geliştirilmiştir. Yöntem, minimum sistem sürdürme maliyetiyle hesaplanan maliyetlerinin doğruluğunu maksimize etmeyi hedeflemektedir. Bu çalışmanın amacl, konteyner terminallerindeki hizmet üretim süreçlerinin maliyetlerini Zaman Esasl Faaliyet Tabanl Maliyetleme yöntemiyle belirlemek ve çıkan sonuçları doğruluk ve uygulanabilirlik açısından değerlendirmektir. Bu amaç doğrultusunda, TCDD İzmir Alsancak Limanı konteyner terminalinde bir uygulama yapılmıştır.

Anahtar Kelimeler: Zaman Esaslı Faaliyet Tabanlı Maliyetleme, Faaliyet Tabanlı Maliyetleme, Liman Issletme Maliyetleri, Konteyner Terminali Maliyetleri.

JEL Sinıflandırması: M41, L91. \section{Terminals \\ Cost Analysis by Applying Time-Driven Activity Based Costing Method in Container}

\section{ABSTRACT}

Container transportation, which can also be called as "industrialization of maritime transportation", gained significant ground in the world trade by offering numerous technical and economic advantages, and accordingly the container terminals have grown up in importance. Increased competition between container terminals puts pressure on the ports to reduce costs and increase operational productivity. To have the right cost information constitutes a prerequisite for cost reduction. Time-Driven Activity Based Costing has been developed as an alternative system based on traditional Activity Based Costing methodology but a simpler and less costly method. It aims to maximize the accuracy of the cost estimates with minimum maintenance costs. The aim of this research is to determine the cost of production process at the container terminals by Time-Driven Activity Based Costing method and to evaluate the outcomes according to accuracy and applicability. For this purpose, an empirical study at TCDD İzmir Alsancak Port has been conducted.

Keywords: Time-Driven Activity Based Costing, Activity Based Costing, Port Operating Costs, Container Terminal Costs.

Jel Classification: M41, L91.

\footnotetext{
* Bu çalışma, R. Şebnem YAŞAR'ın 2015 yılında Dokuz Eylül Üniversitesi Sosyal Bilimler Enstitüsü’nde savunmuş olduğu "Zaman Esaslı Faaliyet Tabanlı Maliyetleme Sisteminin Liman İşletmeciliğinde Uygulama Önerisi” adlı doktora tezinden üretilmiștir.

** Öğr. Gör. Dr. R. Şebnem Yaşar, Dokuz Eylül Üniversitesi, İzmir Meslek Yüksekokulu.
} 


\section{GíRiş}

Pryor'a göre (2010: 81) zamanın para olduğu, evrensel olarak kabul edilmiş bir gerçektir. Zamana dayalı endüstrilerde rekabet eden pek çok yönetici, üretim stratejilerinin geçmişten miras kalan maliyet sistemleri tarafından zayıflatıldığı konusunda hemfikirdir (Hutchinson, 2007: 31). Hutchinson (2007: 38), zaman esaslı muhasebe yaklaşımına ilişkin olarak şu ifadeleri kullanmaktadır: "Yeni ölçü birimi 'zaman' olmalıdır. Belirli bir dönemde gerçekleşen maliyetler sabit kabul edilmeli, değişken gider olmamalıdır. Değişken ve kontrol edilebilir olan tek şey bir sürece ne kadar zaman ayrıldığıdır. 'Fayda', bu süreyi kısaltan herşeydir. Bu bakış açısı sayesinde maliyet muhasebesinin geleneksel sınırları ortadan kalkmaktadır."

Faaliyet Tabanlı Maliyetleme - FTM (Activity Based Costing - ABC), son otuz y1lın en iyi bilinen yönetim muhasebesi yeniliği olarak görülmektedir (Wegmann, 2009: 2). 1980'lerin ortalarından itibaren FTM, her gelirin iyi olmadığını, her müşterinin kâr getirmediğini yöneticilerin görmelerini sağlamıştır (Kaplan ve Anderson, 2007a: 18). Bütün olumlu özelliklerine ve maliyetlere getirdiği yeni bakış açısına rağmen geleneksel FTM sistemlerini oluşturma ve sürdürme zorlukları, bu sistemin etkili ve güncel bir yönetim aracı olmasını engellemiş, kaynak maliyetlerini faaliyetlere dağıtmak için alternatif yöntem arayışlarını tetiklemiştir. Bu doğrultuda, FTM yönteminin öncülerinden olan Robert S. Kaplan, Steven R. Anderson ile birlikte yöntemde bir değişiklik tasarlamışlardır. Bu değişikliklerin başlangıcı 1998'e kadar uzansa da, Zaman Esaslı Faaliyet Tabanlı Maliyetleme - ZEFTM (Time-Driven Activity Based Costing - TDABC) ismi Kasım 2004'ten itibaren literatürde yerini almıştır (Gervais vd., 2010: 1).

Türkiye'de ZEFTM uygulamalarına ilişkin olarak yapılan çalışmalar mevcuttur. Öker ve Adıüzel (2010), Aysan üretim işletmesinde ZEFTM'nin nasıl uygulanabileceğini araştırmışlardır. Araştırma sonucunda, ZEFTM'nin hizmet işletmelerinde uygulanmasının daha uygun ve kolay olduğunu, bununla birlikte kapasitenin zaman ölçüsü olarak ifade edilebildiği üretim işletmeleri için de uygun ve kullanışlı olabileceği sonucuna ulaşmışlardır (Öker ve Adıgüzel, 2010: 91). Kırlığlu ve Atalay (2014), hastane işletmeleri için bir ZEFTM modellemesi yapmışlardıdr. Polat (2011) bir sanayi işletmesinde, Cengiz (2011) mobilya üreten bir işletmede FTM ile ZEFTM uygulaması yapmışlardır. Her iki çalışma da kullanılmayan kapasitenin FTM'de ürün maliyetlerini artıran bir etken olarak ortaya çıktığını vurgulamaktadır. Yükçü ve Gönen (2009), ZEFTM'yi otomobil parçaları üreten bir işletmede uygulayarak, sonuçları FTM ile karşılaştırmalı olarak ele almışlardır. Sonuçta, ZEFTM uygulamasında oluşan maliyet kaymasının daha gerçekçi maliyet bilgilerine ulaşılmasını sağladığı görülmüştür. Benzer şekilde Atmaca ve Terzi (2007), Saban ve İrak (2009), Berikol ve Güner (2016) FTM ile ZEFTM'yi karşılaştıran çalışmalar yapmışlardır. Dalcı vd. (2010), ZEFTM ile bir otelde müşteri kârlılık analizi uygulaması yapmışlardır. 
$\mathrm{Bu}$ çalışmanın amacı, konteyner terminallerindeki hizmet üretim süreçlerinin maliyetlerini ZEFTM yöntemiyle belirlemek ve çıkan sonuçları doğruluk ve uygulanabilirlik açısından değerlendirmektir. Bu bağlamda, öncelikle FTM ve ZEFTM sistemlerinin teorisi üzerinde durulmuştur. Daha sonra, TCDD İzmir Alsancak Limanı konteyner terminalinde yapılan ZEFTM uygulaması anlatılmış ve uygulama sonuçları incelenmiştir. Çalışmanın kullanılan yöntem ve uygulandığ 1 sektör açısından literatüre katkı sağlayacağ düşünülmektedir.

\section{FAALIYET TABANLI MALIYETLEME (FTM)}

Son otuz yıldır yönetim muhasebesi bilgi sistemlerinin belki de en çok tartışılmış yeniliği FTM'dir. Daly (2002: 115), FTM’yi “maliyetlerin sağduyulu bir şekilde dağıtılması yöntemi” olarak tanımlamıştır. Gerektiği gibi uygulandığı ve sürdürüldüğü sürece FTM sistemleri, endirekt maliyetleri kaynak tüketimine göre dağıtmaktadır. Birden çok mamul ya da hizmet sunan işletmelerde, mamul maliyet bilgilerinde bozulmaların oluşması kaçınılmazdır (Cooper ve Kaplan, 1990: 40). FTM, mamullerle maliyetler arasındaki sistematik neden-sonuç ilişkilerini tanımlayarak geleneksel maliyet dağıtım sistemlerine kıyasla daha doğru mamul maliyeti verileri ortaya koymaktadır (Fennema vd., 2005: 168). Stevenson vd. (1996: 25), FTM'yi “Bazı mamullerin, diğer bazı mamullerin masraflarını ödediği ‘örgütsel sosyalizm'in foyası artı meydana çıkmıştır.” şeklinde değerlendirmektedirler.

FTM, temel maliyet objeleri olarak faaliyetlere odaklanmaktadır. FTM, tüm üretim sürecini faaliyetlere bölmekte ve sonra maliyetleri, söz konusu mamulü üretmek için ne kadar faaliyet kullanıldığını temel alarak mamullere dağıtmaktadır. Bir FTM sisteminde mamul maliyetlemesinin temel varsayımı, bir mamulün toplam maliyetinin hammadde maliyetleri ile mamulü üretmek için yapılan tüm değer katıcı faaliyetlerin maliyetlerinin toplamına eşit olduğudur (Gunasekaran ve Sarhadi, 1998: 232; Cokins, 1999: 39). Bir başka deyişle FTM, işletme kaynaklarının gerçekleştirilen faaliyetler tarafından kullanımını modellemekte ve bu faaliyetlerin maliyetlerini mamuller, müşteriler ve hizmetler gibi çıtılarla ilintilendirmektedir.

FTM sistemi, bazı genel üretim giderlerinin üretim miktarıyla orantılı olarak arttığını ancak geri kalanının bu şekilde bir orantılı artış göstermediğini ayırt ederek, farklı seviyelerde maliyet taşıyıcıları ya da dağıtım anahtarları belirlemektedir. Faaliyetlerin maliyetlerini, bu faaliyetlerin tükettiği kaynaklara bağlı olarak mamullere yüklerken birden çok maliyet taşıyıcısı kullanılmasına olanak vererek, maliyetlerin belirlenmesindeki doğruluk payını büyük oranda artırmaktadır. Geleneksel maliyetleme yöntemleri, maliyetleri üretim hacminin doğrusal bir fonksiyonu olarak hesaplarken; FTM maliyetleri, faaliyet seviyesindeki değişikliklerin bir fonksiyonu olarak görmektedir (Labro, 2006: 217). 


\subsection{Faaliyet Tabanlı Maliyetleme Sistemindeki Sorunlar}

Önerdiği değer odaklı yaklaşımına rağmen FTM, evrensel olarak kabul edilen bir sistem olamamıştır. Mamullerin, süreçlerin, hizmetlerin ve müşterilerin maliyet ve kârlılığına 1şık tutan bir sistemin yaygın bir şekilde benimsenmemesi şaşırtıcıdır (Kaplan ve Anderson, 2007a: 5; Gosselin, 2007: 666).

FTM'nin doğru maliyet bilgileri sağlama konusundaki avantajlarına rağmen, analiz için gerekli bilgilerin toplanması ek bir çaba ve harcama gerektirmektedir. $\mathrm{Bu}$ da hız ve verimliliğe dayanan günümüz iş dünyasına uygun değildir. FTM sistemleri; kurması pahalı, devam ettirmesi karmaşık ve değiştirilmesi zor sistemlerdir (Kaplan ve Anderson, 2007a: 6). FTM’yi sürdürmenin yüksek maliyeti, pek çok işletmenin bilgileri sık sık güncellememelerine yol açmış; bu da geçerliliğini yitirmiş yükleme oranları ve doğru olmayan mamul ve müşteri maliyetleri hesaplamalarını beraberinde getirmiştir (Zimmerman, 2011: 524). Maliyet bilgilerinin güncel olmayan verilere dayanması, bu bilgilerin karar alma ve performans değerleme süreçlerinde kullanılamaması sonucunu da doğurmuştur (Geri ve Ronen, 2005: 139).

FTM, kişilerin çalışma zamanlarını nasıl geçirdiklerini hesaplamalarını istemekte ve maliyet dağıtımını bu tahminlere dayanarak yapmaktadır (Kaplan ve Anderson, 2007a: 6). Bunlar objektif olarak doğrulanması zor, niteliği gereği tehlike yaratan sübjektif hesaplamalardır ve yanlış faaliyet tabanlı maliyetlere yol açabilmektedir (Zimmerman, 2011: 524). Çalışanların en iyi niyetli çabalarında bile oluşabilecek hataların dışında, verinin ne için kullanılacağını umursamadan çalışanların cevaplarını saptırmaları ya da tahrif etmeleri riski bulunmaktadır (Kaplan ve Anderson, 2007a: 6). FTM'nin bu sübjektifliği, sistemi oyuna açık hale getirmekte ve karar alma sürecindeki değerini düşürmektedir (Zimmerman, 2011: 524).

Bir başka sorun, görüşme ve anket sürecinin kendisinde ortaya çıkmaktadır. Çalışanlara zamanlarının yüzde kaçını hangi faaliyetler için kullandıkları sorulduğunda, çalışanlar toplam \%100'e ulaşan cevaplar vermekte, çok az kişi çalışmadıkları zamanları bir yüzde olarak belirtmektedir. Bu sebeple, hemen hemen tüm FTM sistemleri kaynakların tam kapasite çalıştıkları varsayımı altında yükleme oranlarını hesaplamaktadır (Kaplan ve Anderson, 2007a: 6). Dolayısıyla da model, kullanılmayan kapasiteyi dikkate almadığı için, teorik olarak hatalı duruma düşmektedir (Kaplan ve Anderson, 2007a: 5).

\section{ZAMAN ESASLI FAALIYET TABANLI MALIYYTLEME (ZEFTM)}

ZEFTM, FTM'ye kıyasla daha basit ve daha az maliyetli, alternatif bir yöntem olarak ortaya çıkmıştır. ZEFTM, geleneksel FTM metodolojisini temel alan, ancak geleneksel FTM uygulamalarından daha kârlı ve daha güçlü yeni bir araç olarak görülmektedir (Yılmaz, 2008: 1). 


\subsection{Zaman Esaslı Faaliyet Tabanlı Maliyetlemenin Teorisi}

ZEFTM, FTM'den farklı olarak, kaynakları ve maliyetleri faaliyetlere yüklememektedir. İşletmedeki farklı kaynak gruplarını (departmanları), kaynak gruplarının maliyetlerini ve pratik kapasitelerini tanımlamakta ve bu bilgiler 1şığında her bir kaynak grubunun birim zaman maliyeti hesaplanmaktadır. Daha sonra, çalışanlarla yapılan görüşmelere dayanarak, işletmede gerçekleştirilen faaliyetler ve bunlara ilişkin zaman denklemleri belirlenmektedir. ZEFTM modelinin temel girdisi, bir faaliyeti gerçekleştirmek için gerekli olan zamandır. ZEFTM, bir faaliyetin gerçekleştirilme süresinin sabit olmadığı, çok değişkenli stokastik süreçlerle belirlendiği varsayımına dayanmaktadır.

Geleneksel FTM, maliyetlemede “itme” modelidir (Yılmaz, 2008: 1). Modele, çeşitli kaynaklara yapılan harcamaların belirlenmesiyle başlanmakta ve her bir kaynakla her mamul ya da hizmetin ilişki yüzdeleri hesaplanmaktadır. Hesaplanan oranlar toplam maliyete uygulanarak maliyet dağıtımı gerçekleştirilmektedir (Yılmaz, 2008: 1). ZEFTM ise aksine, bir "çekme" modelidir. ZEFTM'ye, üretimdeki her bir sabit kaynağın pratik kapasitesinin belirlenmesiyle başlanmaktadır. Daha sonra, birim kapasite maliyetinin hesaplanması için her kaynağın maliyeti pratik kapasiteye bölünmektedir. Her bir faaliyet, hesaplanan birim maliyeti ve kullanılan kapasite miktarını esas alarak sabit üretim kaynaklarının maliyetini kendine çekmektedir (Atkinson, 2007: 43).

ZEFTM'de faaliyet havuzları bulunmamaktadır. ZEFTM, FTM'nin kaynak maliyetlerini faaliyetlere taşıma aşamasını tümüyle atlamakta, dolayısıyla departman maliyetlerini departmanın gerçekleştirdiği pek çok faaliyete dağıtma ihtiyacını da ortadan kaldırmaktadır (Kaplan ve Anderson, 2007c: 39). Böylece, FTM'nin pahalı ve sübjektif zaman dağılımı araştırmalarına da ihtiyaç kalmamaktadır (Kaplan ve Anderson, 2007c: 39).

Geleneksel FTM'de zamanı bir maliyet taşıyıcısı olarak kullanma imkânı varsa da, ZEFTM'de zaman tümüyle farklı bir rol üstlenmektedir. Geleneksel FTM sistemleri, zaman taşıyıcılarını maliyet dağıtım sürecinin ikinci aşamasında uygulamaya sokarken, bu yeni yaklaşım zamanı, maliyetleri direkt olarak kaynaklardan maliyet objelerine taşımakta kullanarak, kaynak maliyetlerini faaliyetlere yükleme basamağını atlamaktadır (Kaplan ve Anderson, 2007b: 17; Hooze vd., 2009: 2).

\subsection{Zaman Esaslı Faaliyet Tabanlı Maliyetleme Süreci}

ZEFTM süreci, kaynak gruplarının belirlenmesi ve tedarik edilen kaynak kapasite maliyetinin hesaplanması, tedarik edilen kaynakların pratik kapasitesinin hesaplanması, kapasite maliyet oranının hesaplanması, her bir faaliyetin talep ettiği kaynak kapasitesinin belirlenmesi ve son olarak maliyet objelerinin maliyetlerinin hesaplanması aşamalarından oluşmaktadır. Bu aşamalar, aşağıda incelenmektedir. 


\subsubsection{Kaynak Gruplarının Belirlenmesi ve Tedarik Edilen Kaynak Kapasite Maliyetinin Hesaplanması}

ZEFTM sürecine kaynak gruplarının belirlenmesiyle başlanır. Bir "kaynak grubu", aynı kaynakları tüketen FTM faaliyetlerinin toplamıdır. Bu kavram, FTM'deki "faaliyet” kavramıyla karışmasını önlemek için ortaya atılmıştır ve örgütsel birim ya da departmanlarla özdeşleştirilmiştir (Gervais vd., 2010: 2). Daha sonra, tedarik edilen kaynak kapasite maliyeti, bir başka ifadeyle her bir departman ya da süreç için tedarik edilen tüm kaynakların toplam maliyeti hesaplanır. Tedarik edilen kaynakların toplam maliyetinin belirlenmesinde, fiili maliyetlerin ya da bütçelenmiş maliyetlerin kullanılması mümkündür.

\subsubsection{Tedarik Edilen Kaynakların Pratik Kapasitesinin Hesaplanması}

ZEFTM'nin ikinci aşamasında, tedarik edilen kaynakların pratik kapasitesi hesaplanır. $\mathrm{Bu}$ aşamada, çalışanların ve makinelerin ortalama ayda kaç gün çalıştıkları ve molalar, eğitimler, toplantılar, bakım \& onarım ve diğer çalışmama sebepleri çıkarıldıktan sonra fiili olarak günde kaç saat ya da dakika çalıştıkları belirlenmektedir. $\mathrm{Bu}$ tutarın çok net hesaplanması gerekmez. Küçük hatalar önemli sorunlar doğurmamaktadır. Hesaplamada yapılan büyük hatalar ise beklenmeyen kapasite fazlası ya da darlığıla belirlenebilmektedir (Kaplan ve Anderson, 2007b: 10).

Pratik kapasite, tahmini olarak hesaplanabildiği gibi, analitik çalışmalarla da hesaplanabilir. Tahmine dayalı yaklaşım, pratik kapasitenin teorik kapasitenin \%80-85'i olduğunu varsaymaktadır (Kaplan ve Anderson, 2007a: 52). Bu şekilde sabit bir pratik kapasite oranının kullanılması, hızlı bir model oluşumu için yeterli olsa da, daha analitik bir yaklaşım daha doğru sonuçlar vermektedir. Analitik yaklaşımda ise pratik kapasite, teorik kapasiteden çalışanların ve makinelerin çalışmadıkları zamanlar çıkartılarak belirlenmektedir (Kaplan ve Anderson, 2007a: 53).

\subsubsection{Kapasite Maliyet Oranının Hesaplanması}

ZEFTM modelinin temel hesaplamalarından bir diğeri, kapasite maliyet oranının, bir başka deyişle her bir kaynak grubunun birim maliyetinin belirlenmesidir. Kapasite maliyet oranı, tedarik edilen kaynak kapasite maliyetinin tedarik edilen kaynakların pratik kapasitesine bölünmesiyle hesaplanır.

Kapasite Maliyet Oranı = Tedarik Edilen Kaynakların Maliyeti / Tedarik Edilen Kaynakların Pratik Kapasitesi

İşlemin payında, departmanla ya da süreçle ilişkili tüm maliyetlerin toplamı yer almaktadır. Payda ise, departmanda ya da süreçte faydalanılan kaynakların pratik kapasitesini temsil etmektedir. Hesaplanan kapasite maliyet oranları, kaynakları siparişlere, ürünlere ve müşterilere taşımakta kullanılmaktadır. 


\subsubsection{Her Bir Faaliyetin Talep Ettiği Kaynak Kapasitesinin Belirlenmesi}

Kapasite maliyet oranının hesaplanmasından sonra, her bir faaliyetin talep ettiği kaynak kapasitesi belirlenir. Bu aşamada, her faaliyetin gerektirdiği kapasite (zaman) hesaplanır. Diğer bir ifadeyle, maliyet objeleri bazında değişen kaynak taleplerini gösterecek zaman öngörüsü yapılır (Polat, 2011: 128).

Zaman ölçümleri; doğrudan gözlem, 50-100 benzer işlemin gerçekleştirilme sürelerinin ortalamasını almak, çalışanlarla mülakatlar ya da anketler yapmak, ya da zaman ölçümlerini işletmenin kendisinden almak gibi pek çok yöntemle sağlanabilmektedir (Kaplan ve Anderson, 2007a: 26). ZEFTM modelinin stratejik maliyetleme hedefi için, işletmelerin kesinliğe değil; doğruluğa ihtiyacı vardır. İlk basamağı kesin bilmek, ikinci basamağı yaklaşık olarak bilmek ve ondalık virgülü doğru yere koymak ZEFTM için yeterli olmaktadır (Kaplan ve Anderson, 2007a: 26). Bu seviyede doğruluk, kolaylıkla ve düşük maliyetle elde edilebilmektedir.

\subsubsection{Maliyet Objelerinin Maliyetlerinin Belirlenmesi}

ZEFTM'nin son aşamasında, maliyet objesinin ihtiyaç duyduğu zamanla kapasite maliyet oranı çarpılarak her bir maliyet objesinin maliyeti hesaplanır.

\subsection{Zaman Denklemleri}

ZEFTM'nin getirdiği en büyük yenilik, zaman taşıyıcıları ve zaman denklemleridir. ZEFTM, faaliyetlerin gerçekleştirildikleri zamana karşılık gelen maliyet taşıyıcılarının kullanımını içeren bir eşdeğerlilik yaklaşımıdır. ZEFTM'nin temel ilkesi, maliyet taşıyıcılarını zaman taşıyıcılarına, yani eşdeğer zamansal birimlere (standart çalışma saatlerine) çevirmektir (Wegmann, 2009: 16). Zaman denklemleri ise, bir faaliyeti gerçekleştirmek için gerekli olan zamanı, zaman taşıyıcılarının bir fonksiyonu olarak gösteren matematiksel denklemlerdir (Hoozee vd., 2012: 465; Everaert ve Bruggeman, 2007: 17).

ZEFTM modelinde, işlem taşıyıcıları (ayar sayısı, malzeme hareket sayısı, sipariş sayısı vb.) yerine zaman taşıyıcıları (ayar süresi, elleçleme süresi, sipariş işleme süresi vb.) kullanılmaktadır. Bunun sebebi, karmaşık ortamlarda bir faaliyetin her zaman aynı miktarda kaynak tüketmemesidir. İşlem özelliklerinin olası her bir kombinasyonu için ayrı bir faaliyet tanımlamaktansa, zaman esaslı yaklaşım kaynak talebini zaman denklemleriyle hesaplamaktadır.

Geleneksel FTM, farklılıkların üstesinden faaliyet sayısını artırarak yani bilinen başlıca varyasyonlara farklı faaliyetlermiş gibi davranarak gelmektedir. FTM modelindeki faaliyet detayındaki artış, veri hesaplama, depolama ve işleme miktarında katlanarak artışa yol açmaktadır (Kaplan ve Anderson, 2007a: 28). ZEFTM modeli ise tüm işletmede faaliyetlerin gerçekleştirilmesi için kullanılan süreçleri taklit etmektedir. Böylece geleneksel FTM modellerine kıyasla daha fazla veri toplama, depolama ve işleme gerekliliği yaratmadan, daha fazla varyasyonu ve karmaşıklığı içine alabilmektedir (Kaplan ve Anderson, 2007b: 8). 
Modelin büyüklüğü, geleneksel FTM'deki gibi katlamalı olarak değil, yalnızca doğrusal olarak artmaktadır (Kaplan ve Anderson, 2007a: 29).

Zaman denklemleri, aşağıdaki şekilde formülleştirilmektedir:

Süreç zamanı $=$ Bireysel faaliyet zamanlarının toplamı

$$
=\beta_{0}+\beta_{1} X_{1}+\beta_{2} X_{2}+\beta_{3} X_{3}+\beta_{4} X_{4}+\ldots .+\beta_{i} X_{i}
$$

$\beta_{0}=$ Temel faaliyeti gerçekleştirmek için gerekli standart zaman

$\beta_{\mathrm{i}}=\mathrm{i}$ ek faaliyeti için hesaplanan zaman

$\mathrm{X}_{\mathrm{i}}=\mathrm{i}$ ek faaliyetinin miktarı

Bir ürün ya da siparişten kaynaklanan süreç karmaşıklığı, denkleme yeni terimlerin eklenmesine yol açsa da süreç, tek bir zaman denklemiyle ifade edilerek modellenmeye devam etmektedir (Kaplan ve Anderson, 2007a: 15). Geleneksel FTM’de, yeni bir faaliyetin modele dâhil edilebilmesi bütün yüzde hesaplamalarının baştan yapılmasını gerektirmektedir. ZEFTM'de ise zaman denklemine yeni faaliyet tarafindan talep edilen kaynak kapasitesini (zamanı) yansitan bir ekleme yapmak yeterli olmaktadır (Kaplan ve Anderson, 2007a: 29). Bu özellik, küçük bir ek maliyet ve çabayla modelin doğruluğunu artırmaktadır.

\section{TCDD İZMİR ALSANCAK LIMMANI KONTEYNER TERMINALİNDE ZAMAN ESASLI FAALIYET TABANLI MALIYETLEME UYGULAMASI}

$\mathrm{Bu}$ çalışmada, ZEFTM sistemiyle konteyner terminallerinde hizmet üretim süreci maliyetlerinin belirlenmesine ilişkin bir uygulama yapılmış ve zaman denklemleri oluşturularak işletmenin üretim maliyetlerine ilişkin bir model ortaya konulmuştur.

\subsection{Araştırmanın Amacı ve Kapsamı}

$\mathrm{Bu}$ çalışmanın amacı, konteyner terminallerindeki maliyet unsurlarını tanımlayarak maliyetleri saptamak ve sunulan hizmetlerin maliyetlerini ZEFTM yöntemi ile belirleyerek çıkan sonuçları doğruluk ve uygulanabilirlik açısından değerlendirmektir.

Araştırma, TCDD İzmir Alsancak Limanı konteyner terminalinde gerçekleştirilmiştir. Uygulamada, terminalde bir yıl içerisinde verilen hizmet süreçleri ve gerçekleşen fiili maliyetler baz alınmıştır.

\subsection{Araştırmanın Metodolojisi}

Çalışmada, limanda gerçekleşmiş fiili maliyet verileri ve terminalde verilen hizmetlere ilişkin istatistik raporlarından elde edilen veriler kullanılmıştır. Kaynak gruplarında gerçekleştirilen her bir faaliyetin süresi, doğrudan gözlem ve yetkili kişilerle yapılan mülakatlar sonucu belirlenmiştir. ZEFTM uygulamasına, kaynak gruplarının belirlenmesi ve kaynak gruplarının toplam maliyetlerinin hesaplanmasıyla başlanmıştır. Çalışanların ve makinelerin çalışma süreleri hesaplanarak pratik kapasite miktarı belirlendikten sonra, kaynak grubunun toplam maliyeti pratik kapasiteye bölünerek kapasite maliyet oranı hesaplanmıştır. Maliyet objeleri için kaynak grupları bazında standart süreler oluşturulmuş, kaynak grubunun 
kapasite maliyet oranıyla standart sürenin çarpılması sonucu maliyetler belirlenmiştir. Kaynak gruplarının maliyetleri toplamı, maliyet objesinin toplam maliyetini vermektedir.

\subsection{Araştırmanın Bulguları}

Araştırmanın bulguları aşamalar halinde aşağıda yer almaktadır.

\subsubsection{Maliyet Objelerinin Tanımlanması}

Konteyner terminallerinde gerçekleştirilen tüm iş süreçleri, "konteyner" odaklıdır. Bir başka ifadeyle, hizmet "konteyner”e verilmektedir. Dolayısıyla, terminalde elleçlenen, yani hizmet alan konteyner, uygulamanın maliyet objesi olarak belirlenmiştir.

\subsubsection{Kaynak Gruplarının Belirlenmesi ve Tedarik Edilen Kaynak Kapasite Maliyetinin Hesaplanması}

Çok sayıda karmaşık lojistik faaliyetlerini içeren taşımacılık ağı sisteminin bir parçası olan konteyner terminalleri, deniz ulaşımı ve karayolu ulaşımı arasında bir arayüz olarak faaliyet göstermenin ötesinde, bundan da önemlisi, tüm ağ sistemi boyunca yüklerin akışını kolaylaştırma görevini de yerine getirebilmelidir (Wang vd., 2005: 19). Konteyner terminallerinde gerçekleşen üretim sürecini, planlama faaliyetleri ve terminal operasyonları olarak iki ana başlık altında incelemek mümkündür.

Konteyner terminallerindeki planlama faaliyetleri, gemi planlama, saha planlama ve CFS (Container Freight Station - Konteyner Yük İstasyonu) planlama olmak üzere üç ana grupta incelenebilir. Gemi planlama 3 ayrı süreçten oluşmaktadır. Bu süreçler, gemilerin hangi rıhtıma yanaşacağının belirlendiği rıhtım planlama süreci, konteynerlerin gemide hangi lokasyona yerleştirileceklerinin ya da hangi lokasyondan alınacaklarının belirlendiği gemi istif planlama süreci ve yükleme/boşaltma faaliyetlerini gerçekleştirecek vincin belirlendiği rıhtım vinci planlamadır sürecidir (Steenken vd., 2004: 17). Saha planlamanın öncelikli görevi ise, istife yerleştirilecek bir konteyner için blok ve söz konusu blokta yer seçimi yapmaktır. CFS, boş konteynerlerin iç dolumu ya da dolu konteynerlerin iç boşaltımı yapılan alanı ifade etmektedir. Buradaki operasyonların planlanma süreci CFS planlama olarak adlandırılmaktadır.

Konteyner terminali operasyonlarını ise dört alana ayırmak mümkündür. Bunlar; gemi operasyonları, saha operasyonları, CFS operasyonları ve kap1 operasyonlarıdır. Gemi operasyonları, konteynerlerin gemiden boşaltılmasını, konteynerlerin gemiye yüklenmesini ve gemiye verilen diğer hizmetleri kapsayan süreçtir. Saha operasyonları, konteynerlerin terminal sahası içinde taşınma, istiflenme ve muhafaza edilmelerine ilişkin faaliyetleri kapsamaktadır. CFS operasyonları, konteyner iç dolum ve iç boşaltım hizmetlerinin yer aldığı süreçtir. Kapı operasyonları ise, konteynerlerin terminale giriş ve terminalden çıkış 
süreçlerinde gerçekleştirilen faaliyetleri kapsamaktadır. Şekil 1'de konteynerlerin terminal içindeki hareketleriyle operasyonel alanlar bütünleşik olarak gösterilmektedir.

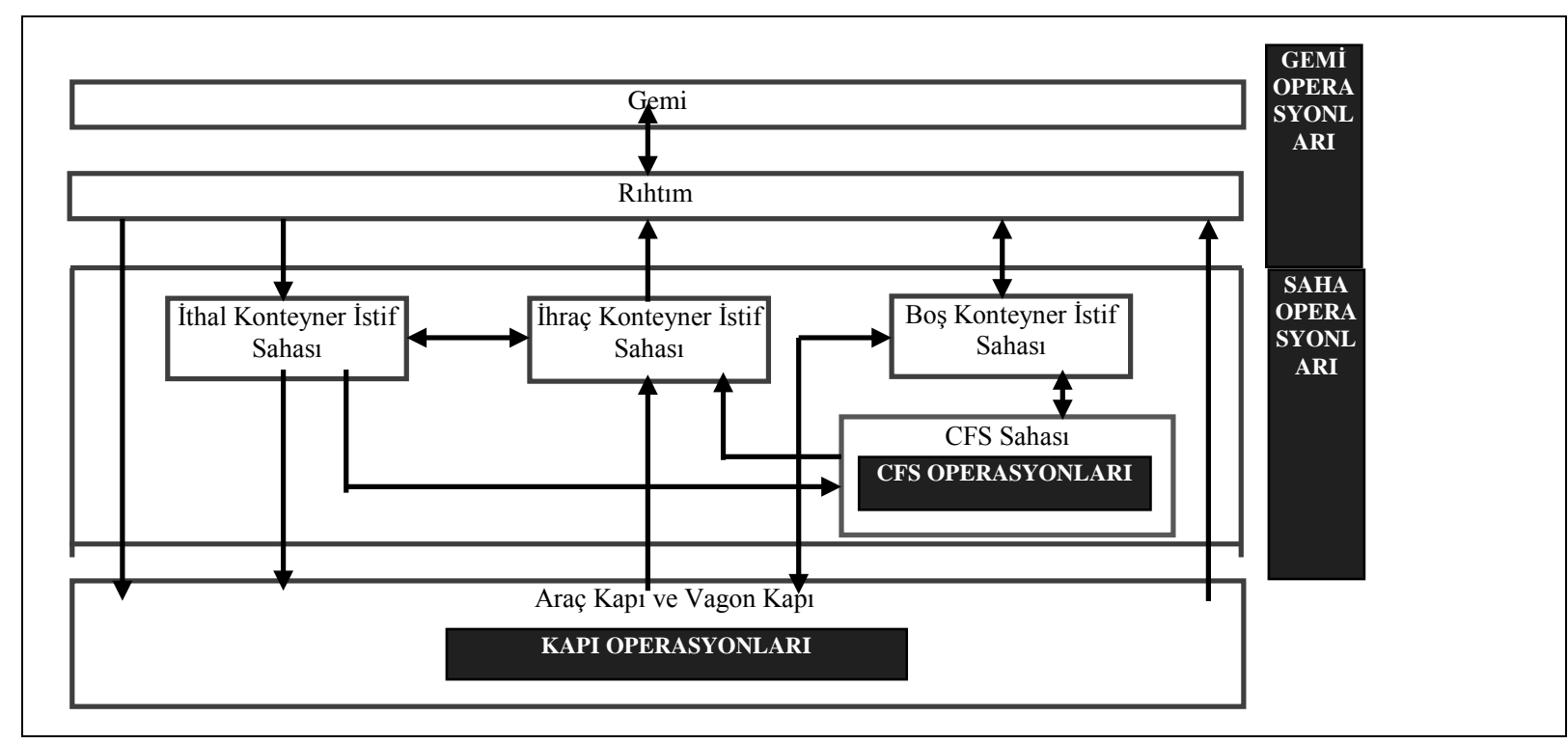

Şekil 1. Konteynerlerin Terminal İçerisindeki Hareketleri ve Operasyonel Alanlar

ZEFTM uygulamasında; gemi planlama, saha planlama ve CFS planlamadan oluşan planlama faaliyetleri ayrı kaynak grupları olarak ele alınmıştır. Terminal operasyonlarında ise, CFS operasyonları ve kapı operasyonları kaynak grupları olarak tanımlanmıştır. Buna karşılık gemi operasyonları; gemi hizmetleri ve yükleme/boşaltma olmak üzere iki kaynak grubuna bölünmüştür. Benzer şekilde saha operasyonları da, konteyner hareketleri ve ardiye hizmetleri olarak iki kaynak grubuna ayrılmıştır. Kaynak grupları ve tedarik edilen kaynakların kapasite maliyetleri Tablo 1'de yer almaktadır.

Tablo 1. Tedarik Edilen Kaynak Kapasite Maliyetleri

\begin{tabular}{|c|c|}
\hline KAYNAK GRUPLARI & TOPLAM MALIYETLER (TL) \\
\hline Gemi Planlama & $512.347,12$ \\
\hline Saha Planlama & $571.615,52$ \\
\hline CFS Planlama & $142.903,88$ \\
\hline Gemi Hizmetleri & 2.313.290,09 \\
\hline Yükleme/Boşaltma & 23.586.194,66 \\
\hline Konteyner Hareketleri & 25.977.168,95 \\
\hline Ardiye Hizmetleri & 425.895,51 \\
\hline CFS Operasyon & 7.166.707,58 \\
\hline Kap1 Operasyon & 2.317.210,45 \\
\hline TOPLAM & 63.013.333,77 \\
\hline
\end{tabular}




\subsubsection{Kaynak Gruplarının Pratik Kapasitelerinin ve Kapasite Maliyet Oranlarının (KMO) Hesaplanması, Faaliyetlerin Talep Ettikleri Kaynak Kapasitelerinin Belirlenmesi}

$\mathrm{Bu}$ aşamada önce, işçilerin ve makinelerin teorik olarak çalışabilecekleri sürelerden, normal şartlar altında oluşabilecek boşa geçen süreler çıkartılarak her bir kaynak grubunun pratik kapasitesi hesaplanmıştır. Normal şartlar altında oluşan boşa geçen sürelerin, işçilerde teorik kapasitenin \%15’i, makinelerde ise \%20'si olarak gerçekleştiği varsayılmıştır. Daha sonra, kaynak gruplarının toplam maliyetleri pratik kapasite miktarına bölünerek her bir kaynak grubunun kapasite maliyet oranı (KMO) hesaplanmıştır. Hesaplamaların sonuçları Tablo 2'de gösterilmektedir.

Tablo 2. Kaynak Gruplarının Pratik Kapasiteleri ve Kapasite Maliyet Oranları

\begin{tabular}{|l|r|r|l|}
\cline { 2 - 4 } \multicolumn{1}{c|}{} & TOPLAM MALIYET & PRATIK KAPAS ITE & \multicolumn{1}{c|}{ KMO } \\
\hline Gemi Planlama & $512.347,12$ & $815.507,00 \mathrm{dk}$ & $0,63 \mathrm{TL} / \mathrm{dk}$ \\
\hline Saha Planlama & $571.615,52$ & $937.571,25 \mathrm{dk}$ & $0,61 \mathrm{TL} / \mathrm{dk}$ \\
\hline CFS Planlama & $142.903,88$ & $242.492,25 \mathrm{dk}$ & $0,59 \mathrm{TL} / \mathrm{dk}$ \\
\hline Gemi Hizmetleri & $2.313 .290,09$ & $1.477 .947,75 \mathrm{dk}$ & $1,57 \mathrm{TL} / \mathrm{dk}$ \\
\hline Yükleme/Boşaltma & $23.586 .194,66$ & $27.764 .597,00 \mathrm{dk}$ & $0,85 \mathrm{TL} / \mathrm{dk}$ \\
\hline Konteyner Hareketleri & $25.977 .168,95$ & $60.149 .415,10 \mathrm{dk}$ & $0,43 \mathrm{TL} / \mathrm{dk}$ \\
\hline Ardiye Hizmetleri & $1.166,84$ & $15.280,00 \mathrm{TEU}$ & $0,08 \mathrm{TL} / \mathrm{TEU}$ \\
\hline CFS Operasyon & $7.166 .707,58$ & $3.570 .613,38 \mathrm{dk}$ & $2,01 \mathrm{TL} / \mathrm{dk}$ \\
\hline Kap1 Operasyon & $2.317 .210,45$ & $1.396 .125,00 \mathrm{dk}$ & $1,66 \mathrm{TL} / \mathrm{dk}$ \\
\hline
\end{tabular}

Tablo 2'de görüldüğü gibi, ardiye hizmetleri dışındaki tüm kaynak gruplarının pratik kapasitesi zaman birimi (dk) cinsinden hesaplanırken, ardiye hizmetlerinin pratik kapasitesi TEU olarak hesaplanabilmiştir. Konteyner ölçü birimi olan TEU (Twenty-foot Equivalent Unit), 20' standart konteyner temel alınarak oluşturulmuş bir kavramdır. Diğer konteynerler $20^{\prime}$ 'in eşdeğer birimleri cinsinden ölçülür. Örneğin, bir adet 40' konteyner iki adet 20' konteynere yani 2 TEU'ya eşdeğerdir. Ardiye hizmetleri kaynak grubu faaliyetlerinin maliyeti, konteynerin terminalde kaldığı sürenin yanı sıra büyüklüğünden de etkilendiği için, kapasitesini terminalin TEU kapasitesi olarak ifade etmek daha uygun olmaktadır.

Daha sonra, kaynak gruplarında yer alan her bir faaliyetin dönem içinde talep ettiği kaynak kapasitesi, bir başka ifadeyle, faaliyetlerin gerçekleştirilme süreleri hesaplanmıştır. Bu süreler Tablo 3’te gösterilmektedir. 
Tablo 3. Kaynak Gruplarında Yer Alan Faaliyetlerin Gerçekleştirilme Süreleri

\begin{tabular}{|c|c|}
\hline KAYNAK GRUPLARINDA GERÇEKLEŞ TIRIILEN FAALIYETLER & $\begin{array}{c}\text { İşçilik Saati + Makine Saati } \\
\text { (dk/kont.) }\end{array}$ \\
\hline \multicolumn{2}{|l|}{ GEMI PLANLAMA KAYNAK GRUBU } \\
\hline - İlk kez limana gelen geminin ve gemi Bay Plan'ının sisteme tanıtılması & 0,02 \\
\hline - Gelen geminin gemi line, sefer, ETA ve yük detay bilgilerinin sisteme girilmesi & 0,02 \\
\hline - Gemi ve rihtımların durumuna göre rihtım planlamasının y apılması & 0,27 \\
\hline - Sistem üzerinde gemi y anaştırma ve gemi ay rılma işlemlerinin yapılması & 0,06 \\
\hline - Acenteden gelen konteyner yükleme ve tahliye listelerinin sisteme aktarılması & 0,05 \\
\hline - Gemiye hizmet verecek postanın/postaların kurulması ve zaman çizelgelerinin hazırlanması & 0,16 \\
\hline - Boșaltılacak konteynerlerin hangi sırayla gemiden alınacağına ilișkin boșaltma planlamasının yapılması & 0,34 \\
\hline $\begin{array}{l}\text { - Yüklenecek konteynerlerin hangi sırayla sahadan alınacağına ve geminin hangi ambarına konacağına ilişkin yükleme } \\
\text { planlamasının y apılması }\end{array}$ & 0,55 \\
\hline \multicolumn{2}{|l|}{ S AHA PLANLAMA KAYNAK GRUBU } \\
\hline $\begin{array}{l}\text { - Gemilerden boşaltılacak konteynerler için uy gun boyutlarda terminal sahalarının oluşturulması ve rıhtım ile istif } \\
\text { sahaları arasındaki konteyner hareketlerinin planlanması }\end{array}$ & 0,29 \\
\hline $\begin{array}{l}\text { - Gemilere yüklenecek kontey nerlere ilişkin planlamanın y apılması ve istif sahaları ile rıhtım arasındaki konteyner } \\
\text { hareketlerinin planlanması }\end{array}$ & 0,24 \\
\hline - Karay oluy la limana gelecek konteynerlerin saha planlamasının y apılması & 1,23 \\
\hline - Demiry oluy la limana gelecek konteynerlerin saha planlamasının yapılması ve konteyner hareketlerinin planlanması & 1,28 \\
\hline - Karayoluy la çıkış y apacak konteyner talep lerinin planlanması & 0,48 \\
\hline - Demiry oluy la çıkış y apacak konteyner hareketlerinin planlanması & 0,94 \\
\hline - İstif sahalarıy la CFS sahası arasındaki konteyner hareketlerinin planlanması & 0,61 \\
\hline - Terminal içindeki diğer konteyner hareketlerinin planlanması & 0,31 \\
\hline \multicolumn{2}{|l|}{ CFS PLANLAMA KAYNAK GRUBU } \\
\hline - Konteyner iç dolum faaliy etlerinin planlanması & 2,5 \\
\hline - Konteyner iç boşaltım faaliy etlerinin planlanması & 3 \\
\hline - İç boşaltımı yapılan konteynerlerdeki mallar için çıkış ve mal teslim işlemlerinin yapılması & 4,5 \\
\hline \multicolumn{2}{|l|}{ GEMI HIZMETLERİ KAYNAK GRUBU } \\
\hline - Gemiden palamar halatının alınıp bağlanması & 120 \\
\hline - Palamar halatının çözülmesi & 80 \\
\hline - Gemiye tatlı su verilmesi & 15 \\
\hline - Geminin katı atıklarının alınmas1 & 30 \\
\hline - Geminin sıv1 atıklarının alınması & 180 \\
\hline \multicolumn{2}{|l|}{ YÜKLEME/BOŞ ALTMA KAYNAK GRUBU } \\
\hline - Ambar kapaklarının açılarak gemi üzerinde bırakılması & 28 \\
\hline - Ambar kapaklarının açılarak rıhtıma indirilmesi & 55 \\
\hline - Rıhtıma indirilmiş ambar kapaklarının gemiye çıkarılması & 55 \\
\hline - Ambar kapaklarının kapatılması & 60 \\
\hline - Konteynerlerin istif bağlarının çözülmesi (unlashing) & 30 \\
\hline - Konteynerlerin istif bağlarının takılması (lashing) & 60 \\
\hline - Konteyner pabuçlarının (twistlock) takılması & 1 \\
\hline - Konteyner pabuçlarının (twistlock) sökülmesi & 1 \\
\hline - 20' konteynere ekstra pabuçlarının takılması & 2 \\
\hline - 20' konteynerin ekstra pabuçlarının sökülmesi & 1 \\
\hline - Gantry vincin konteyneri çekiciden/rihtımdan alması ve gemiye bırakması & 15 \\
\hline - Gantry vincin konteyneri gemiden alması ve çekiciye/rıhtıma bırakması & 12,5 \\
\hline - Gantry vincin konteyneri gemiden alması ve gemide bir başka yere bırakması & 8 \\
\hline - Mobil vincin konteyneri çekiciden/rihtımdan alması ve gemiye bırakması & 17,5 \\
\hline - Mobil vincin konteyneri gemiden alması ve çekiciye/rıhtıma bırakması & 12,5 \\
\hline - Mobil vincin konteyneri gemiden alması ve gemide bir başka yere bırakması & 8 \\
\hline - Gemi puantörünün giriş yapacak konteynerlere ilişkin kontrolleri & 1 \\
\hline - Gemi puantörünün yükleme hareketini sisteme girmesi & 1 \\
\hline - Gemi puantörünün tahliye hareketini sisteme girmesi & 1 \\
\hline - Spreader'e ekstra parça takılması & 90 \\
\hline - Spreader'e takılmış olan ekstra parçaların sökülmesi & 30 \\
\hline - Sapanlama y ap 1lması & 40 \\
\hline - Sapanlamanın sökülmesi & 20 \\
\hline
\end{tabular}




\begin{tabular}{|c|c|}
\hline KAYNAK GRUPLARINDA GERÇEKLEŞ TIRIILEN FAALIYETLER & $\begin{array}{c}\text { İşçilik Saati + Makine Saati } \\
\text { (dk/kont.) }\end{array}$ \\
\hline \multicolumn{2}{|l|}{ KONTEYNER HAREKETLERI KAYNAK GRUBU } \\
\hline - RTG'nin konteyneri çekiciden alması ve istife yerleştirmesi & 8 \\
\hline - RTG'nin konteyneri istiften alması ve çekiciye/y ere bırakması & 8 \\
\hline - Reachstacker'ın konteyneri çekiciden alması ve istife yerleştirmesi & 6 \\
\hline - Reachstacker'ın konteyneri istiften alması ve çekiciye/y ere bırakması & 6 \\
\hline - Boş konteyner vincinin konteyneri çekiciden/yerden alması ve istife yerleștirmesi & 5 \\
\hline - Boș konteyner vincinin konteyneri istiften alması ve çekiciye/y ere bırakması & 5 \\
\hline - Çekicinin rihtım ile ithal konteyner istif sahası arasındaki hareketi & 10 \\
\hline - Çekicinin rıhtım ile ihraç konteyner istif sahası arasındaki hareketi & 10 \\
\hline - Çekicinin rihtım ile boș konteyner istif sahası arasındaki hareketi & 10 \\
\hline - C ekicinin ithal konteyner istif sahası ile CFS sahası arasındaki hareketi & 10 \\
\hline - Çekicinin ihraç konteyner istif sahası ile CFS sahası arasındaki hareketi & 10 \\
\hline - Çekicinin boş konteyner istif sahası ile CFS sahası arasındaki hareketi & 10 \\
\hline - Çekicinin ithal konteyner istif sahası ile vagon sahası arasındaki hareketi & 10 \\
\hline - Çekicinin ihraç konteyner istif sahası ile vagon sahası arasındaki hareketi & 10 \\
\hline - Çekicinin boş konteyner istif sahası ile vagon sahası arasındaki hareketi & 10 \\
\hline - C ekicinin ithal konteyner istif sahası ile ihraç konteyner istif sahası arasındaki hareketi & 10 \\
\hline - C ekicinin ithal konteyner istif sahası ile kantar arasındaki hareketi & 15 \\
\hline - Cekicinin rihtımla termal (reefer) konteyner alanı arasındaki hareketi & 10 \\
\hline - Cekicinin ithal konteyner istif sahasıyla ambar önü arasındaki hareketi & 10 \\
\hline - Konteynerin vagondan indirilmesi & 6 \\
\hline - Konteynerin vagona yüklenmesi & 6 \\
\hline - Sapanlama yapılmasi & 40 \\
\hline - Sapanlamanın sökülmesi & 20 \\
\hline $\begin{array}{l}\text { - Diğer hareketler (konteynerin istifteki yerinin değiştirilmesi, CFS sahasına götürülüp daha sonra işlemden } \\
\text { vazgeçilmesi, tamir atöly esine götürülmesi, atöly eden istife getirilmesi, vb.) }\end{array}$ & 10 \\
\hline \multicolumn{2}{|l|}{ CFS OPERAS YON KAYNAK GRUBU } \\
\hline - Konteynerin mühürünün kırılması & 1 \\
\hline - Konteynerin mühürlenmesi & 1 \\
\hline - Konteynerin kilidinin sökülmesi & 1 \\
\hline - Konteynerin kilidinin takılması & 1 \\
\hline - Konteynerin içinin süpürülmesi & 5 \\
\hline - Eşyanın konteynerin içine forklift'le yüklenmesi & 40 \\
\hline - Eşyanın konteynerin içine insan gücüyle yüklenmesi & 90 \\
\hline - Konteynerin içindeki eşy anın forklift'le boşaltılması & 40 \\
\hline - Konteynerin içindeki eşy anın insan gücüyle boşaltılması & 90 \\
\hline - Konteyner içindeki malların istif bağlarının sökülmesi (konteyner içi unlashing) & 10 \\
\hline - Konteyner içine yüklenen malların istif bağlarının yapılması (konteyner içi lashing) & 15 \\
\hline - CFS puantörünün iç boșaltım hareketini sisteme girmesi & 1 \\
\hline - CFS puantörünün iç dolum hareketini sisteme girmesi & 1 \\
\hline \multicolumn{2}{|l|}{ KAPI OPERAS YON KAYNAK GRUBU } \\
\hline - Konteyner almak ya da bırakmak üzere karay oluyla giriș yapan araç plakasının sistem girișinin y apılması & 2 \\
\hline - Kapı puantörünün çıkıș yapacak konteynere ilişkin kontrolleri ve sistem girișini y apması & 2 \\
\hline - Kap1 puantörünün giriș y apacak konteynere ilișkin kontrolleri ve sistem girișini yapmas1 & 2 \\
\hline - Vagon puantörünün çıkıs yapacak konteynere ilișkin kontrolleri ve sistem girișini yapması & 2 \\
\hline - Vagon puantörünün giriş yapacak konteynere ilişkin kontrolleri ve sistem girișini y apmas1 & 2 \\
\hline
\end{tabular}

Daha sonra, Tablo 3'te yer alan süreler ile dönem içinde gerçekleştirilen faaliyet adetleri çarpılmış, kaynak gruplarının Tablo 4'te yer alan yıllık fiili kapasiteleri hesaplanmıştır. 
Tablo 4. Kaynak Gruplarının Fiili Kapasiteleri

\begin{tabular}{|l|c|}
\cline { 2 - 2 } \multicolumn{1}{c|}{} & Fïil KAPAS ITE \\
\hline Gemi Planlama & $733.572,00 \mathrm{dk}$ \\
\hline Saha Planlama & $600.210,00 \mathrm{dk}$ \\
\hline CFS Planlama & $176.545,00 \mathrm{dk}$ \\
\hline Gemi Hizmetleri & $377.692,00 \mathrm{dk}$ \\
\hline Yükleme/Boşaltma & $9.233 .617,71 \mathrm{dk}$ \\
\hline Konteyner Hareketleri & $18.753 .165,26 \mathrm{dk}$ \\
\hline Ardiye Hizmetleri & $12.773,00 \mathrm{TEU}$ \\
\hline CFS Operasyon & $2.738 .848,00 \mathrm{dk}$ \\
\hline Kap1 Operasyon & $1.609 .614,00 \mathrm{dk}$ \\
\hline
\end{tabular}

\subsubsection{Maliyet Objelerinin Maliyetlerinin Hesaplanması}

Operasyonların konteynerlerin hareket şekline göre ayrımında dört farklı alan ortaya çıkmaktadır. Bunlar, dolu konteynerlerin kara yönündeki hareketleri, dolu konteynerin deniz yönündeki hareketleri, boş konteyner hareketleri ve transit konteyner hareketleridir.

Her bir ana grupta yer alan farklı hareket seçeneklerinde, konteynerlerin tamamı için gerçekleştirilen standart faaliyetler ile bazı konteynerler için gerçekleştirilen standart dışı faaliyetler kaynak grupları bazında belirlenmiş ve her bir hareket seçeneğinin standart süresi hesaplanmıştır. Daha sonra, standart süreler kapasite maliyet oranıyla çarpılarak, maliyet objesinin kaynak grubuyla ilişkili maliyet payı belirlenmiştir. Tüm kaynak grupları için ayrı ayrı hesaplanan tutarların toplamı, maliyet objesinin maliyetini oluşturmaktadır.

\subsubsection{Kara Yönünde Hareket Eden Dolu Konteyner Maliyetleri}

Kara yönünde hareket eden dolu konteyner aşağıdaki 4 hareketten birini yapacaktır:

1. Konteyner, gemiden boşaltıldıktan sonra, doğrudan mal sahibinin aracına yüklenerek limanı terk eder.

2. Konteyner, gemiden boşaltılarak istife alınır. Bir süre istifte muhafaza edildikten sonra, mal sahibinin araciyla karayoluyla limanı terk eder.

3. Konteyner, gemiden boşaltılarak istife alınır. Bir süre istifte muhafaza edildikten sonra demiryoluyla limanı terk eder.

4. Konteyner, gemiden boşaltılarak istife alınır. Bir süre istifte muhafaza edildikten sonra iç boşaltımı yapılmak üzere CFS sahasına alınır. Burada iç boşaltımı yapılır ve boş konteyner haline gelir. Mal sahibi, yalnızca konteynerin içindeki malın çıkışını yapar.

Önce, bu dört hareket seçeneği için gerçekleştirilen faaliyetlerin standart süreleri belirlenmiş; daha sonra, her bir hareket seçeneğinin maliyeti hesaplanmıştır. Yapılan işlemler Tablo 11'de gösterilmektedir. 
Tablo 5. Kara Yönünde Hareket Eden Dolu Konteyner Hareket Seçeneklerinin Standart Süreleri ve Maliyetleri

\begin{tabular}{|c|c|c|c|c|c|c|c|c|c|}
\hline & \multicolumn{4}{|c|}{ STANDART SÜRELER } & \multirow{3}{*}{ KMO } & \multicolumn{4}{|c|}{ MALIYET (TL) } \\
\hline & \multicolumn{4}{|c|}{ HAREKET SEÇENEKLERİ } & & \multicolumn{4}{|c|}{ HAREKET SEÇENEKLERİ } \\
\hline & 1 & 2 & 3 & 4 & & \begin{tabular}{l|l}
1 &
\end{tabular} & 2 & 3 & 4 \\
\hline Gemi Planlama & 1,22 & 1,22 & 1,22 & 1,22 & 0,63 & 0,77 & 0,77 & 0,77 & 0,77 \\
\hline Saha Planlama & 0,00 & 0,77 & 1,22 & 0,90 & 0,61 & 0,00 & 0,47 & 0,75 & 0,55 \\
\hline CFS Planlama & 0,00 & 0,00 & 0,00 & 7,50 & 0,59 & 0,00 & 0,00 & 0,00 & 4,43 \\
\hline Gemi Hizmetleri & 0,45 & 0,45 & 0,45 & 0,45 & 1,57 & 0,71 & 0,71 & 0,71 & 0,71 \\
\hline Yükleme/Boşaltma & 15,95 & 15,95 & 15,95 & 15,95 & 0,85 & 13,56 & 13,56 & 13,56 & 13,56 \\
\hline Konteyner Hareketleri & 0,00 & 26,00 & 42,00 & 36,00 & 0,43 & 0,00 & 11,18 & 18,06 & 15,48 \\
\hline Ardiye Hizmetleri & 0,00 & 7,00 & 7,00 & 7,00 & $\mathbf{0 , 0 8}$ & 0,00 & 0,56 & 0,56 & 0,56 \\
\hline CFS Operasyon & 0,00 & 0,00 & 0,00 & 53,00 & 2,01 & 0,00 & 0,00 & 0,00 & 106,53 \\
\hline Kap1 Operasyon & 4,00 & 4,00 & 2,00 & 2,00 & 1,66 & 6,64 & 6,64 & 3,32 & 3,32 \\
\hline & & & & TO PLA & MALIYET & 21,68 & 33,89 & 37,73 & 145,90 \\
\hline
\end{tabular}

\subsubsection{Deniz Yönünde Hareket Eden Dolu Konteyner Maliyetleri}

Deniz yönünde hareket eden dolu konteyner, aşağıdaki 4 hareketten birini yapacaktır:

1. Konteyner, mal sahibinin aracıyla kapıdan giriş yapar, aynı araçla bekleme yapmaksızın doğrudan rıhtıma gider, gemiye yüklenir ve limanı terk eder.

2. Konteyner, mal sahibinin aracıyla karayolundan limana giriş yapar ve istife alınır. Bir süre istifte muhafaza edildikten sonra gemiye yüklenir ve limanı terk eder.

3. Konteyner, demiryoluyla limana giriş yapar ve vagon sahasından istif sahasına taşınarak istife alınır. Bir süre istifte muhafaza edildikten sonra gemiye yüklenir ve limanı terk eder.

4. Mal sahibi, malları limana kendi araciyla getirir ve bu mallar CFS sahasinda konteynere yerleştirilir. İç dolumu yapılan konteyner istife alınır. Bir süre istifte muhafaza edildikten sonra gemiye yüklenir ve limanı terk eder.

Öncelikle, bu dört hareket seçeneği için gerçekleştirilen faaliyetlerin standart süreleri belirlenmiş; daha sonra, her bir hareket seçeneğinin maliyeti hesaplanmıştır. Yapılan işlemler Tablo 12'de gösterilmektedir. 
Tablo 6. Deniz Yönünde Hareket Eden Dolu Konteyner Hareket Seçeneklerinin Standart Süreleri ve Maliyetleri

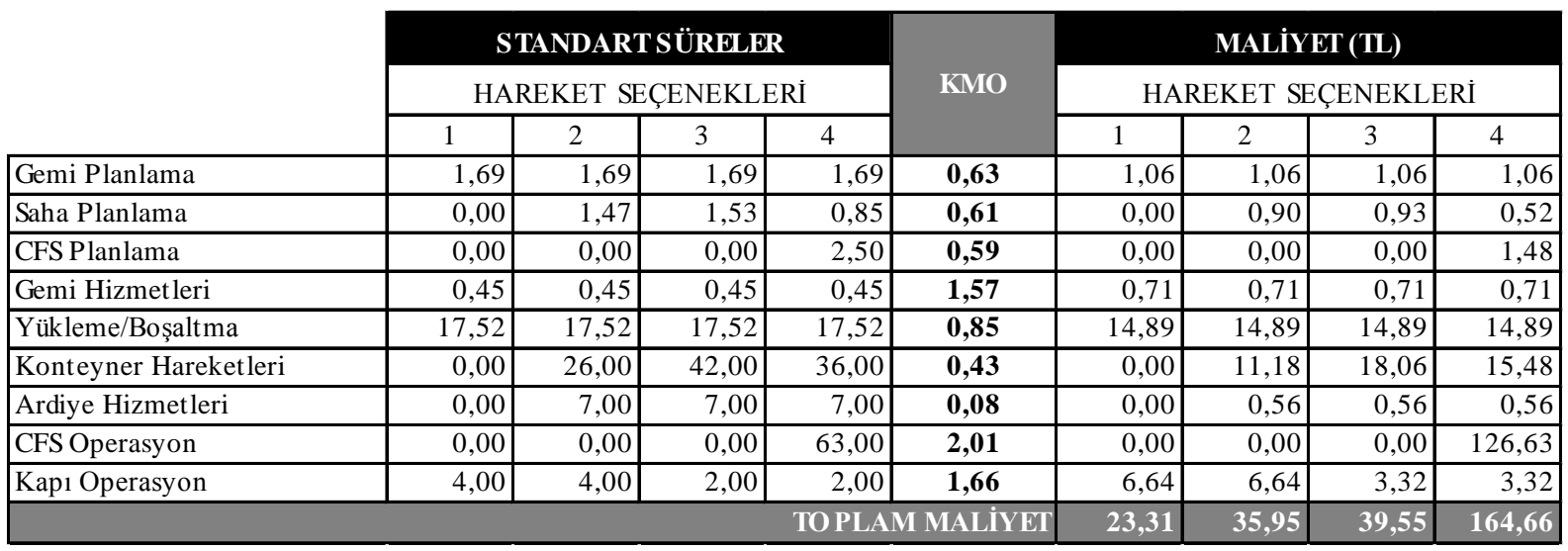

\subsubsection{Boş Konteyner Maliyetleri}

Boş konteynerin hareket seçenekleri, kısaca aşağıdaki şekilde özetlenebilir:

1. Limana denizyoluyla giriş yapıp, denizyoluyla limanı terk etmek.

2. Limana denizyoluyla giriş yapıp, karayoluyla limanı terk etmek.

3. Limana denizyoluyla giriş yapıp, demiryoluyla limanı terk etmek.

4. Limana denizyoluyla giriş yapıp, iç dolum sonucu dolu konteynere dönüşmek.

5. Limana karayoluyla giriş yapıp, denizyoluyla limanı terk etmek.

6. Limana karayoluyla giriş yapıp, karayoluyla limanı terk etmek.

7. Limana karayoluyla giriş yapıp, demiryoluyla limanı terk etmek.

8. Limana karayoluyla giriş yapıp, iç dolum sonucu dolu konteynere dönüşmek.

9. Limana demiryoluyla giriş yapıp, denizyoluyla limanı terk etmek.

10. Limana demiryoluyla giriş yapıp, karayoluyla limanı terk etmek.

11. Limana demiryoluyla giriş yapıp, demiryoluyla limanı terk etmek.

12. Limana demiryoluyla giriş yapıp, iç dolum sonucu dolu konteynere dönüşmek.

13. İç boşaltım sonucu boş konteynere dönüşüp, denizyoluyla limanı terk etmek.

14. İç boşaltım sonucu boş konteynere dönüşüp, karayoluyla limanı terk etmek.

15. İç boşaltım sonucu boş konteynere dönüşüp, demiryoluyla limanı terk etmek.

16. İç boşaltım sonucu boş konteynere dönüşüp, iç dolum yapılarak tekrar dolu konteynere dönüşmek.

Boş bir konteynerin yapabileceği 16 hareket seçeneğinin her biri için standart süreler belirlenmiş; daha sonra, her bir hareket seçeneğinin maliyeti hesaplanmıştır. Hareket seçeneklerinin standart süreleri Tablo 13’te gösterilmektedir. 
Tablo 7. Boş Konteyner Hareket Seçeneklerinin Standart Süreleri

\begin{tabular}{|c|c|c|c|c|c|c|c|c|c|c|c|c|c|c|c|c|}
\hline & \multicolumn{16}{|c|}{ STANDART S ÜRELER } \\
\hline & \multicolumn{16}{|c|}{ HAREKET SEÇENEKLERI } \\
\hline & 1 & 2 & 3 & 4 & 5 & 6 & 7 & 8 & 9 & 10 & 11 & 12 & 13 & 14 & 15 & 16 \\
\hline Gemi Planlama & 2,91 & 1,22 & 1,22 & 1,22 & 1,69 & 0,00 & 0,00 & 0,00 & 1,69 & 0,00 & 0,00 & 0,00 & 1,69 & 0,00 & 0,00 & 0,00 \\
\hline Saha Planlama & 0,53 & 0,77 & 1,23 & 0,90 & 1,47 & 1,71 & 2,17 & 1,84 & 1,52 & 1,76 & 2,22 & 1,89 & 0,85 & 1,09 & 1,55 & 1,22 \\
\hline \begin{tabular}{|l|l|} 
CFS Planlama \\
\end{tabular} & 0,00 & 0,00 & 0,00 & 0,00 & 0,00 & 0,00 & 0,00 & 0,00 & 0,00 & 0,00 & 0,00 & 0,00 & 0,00 & 0,00 & 0,00 & 0,00 \\
\hline Gemi Hizmetleri & 0,90 & 0,45 & 0,45 & 0,45 & 0,45 & 0,00 & 0,00 & 0,00 & 0,45 & 0,00 & 0,00 & 0,00 & 0,45 & 0,00 & 0,00 & 0,00 \\
\hline Yükleme/Boşaltma & 33,47 & 15,95 & 15,95 & 15,95 & 17,52 & 0,00 & 0,00 & 0,00 & 17,52 & 0,00 & 0,00 & 0,00 & 17,52 & 0,00 & 0,00 & 0,00 \\
\hline Konteyner Hareketleri & 30,00 & 20,00 & 36,00 & 30,00 & 20,00 & 10,00 & 26,00 & 20,00 & 36,00 & 26,00 & 42,00 & 36,00 & 30,00 & 20,00 & 36,00 & 30,00 \\
\hline Ardiye Hizmetleri & 7,00 & 7,00 & 7,00 & 7,00 & 7,00 & 7,00 & 7,00 & 7,00 & 7,00 & 7,00 & 7,00 & 7,00 & 7,00 & 7,00 & 7,00 & 7,00 \\
\hline \begin{tabular}{|l|} 
CFS Operasy on \\
\end{tabular} & 0,00 & 0,00 & 0,00 & 0,00 & 0,00 & 0,00 & 0,00 & 0,00 & 0,00 & 0,00 & 0,00 & 0,00 & 0,00 & 0,00 & 0,00 & 0,00 \\
\hline Kap1 Operasyon & 0,00 & 4,00 & 2,00 & 0,00 & 4,00 & 8,00 & 6,00 & 4,00 & 2,00 & 6,00 & 4,00 & 2,00 & 0,00 & 4,00 & 2,00 & 0,00 \\
\hline
\end{tabular}

Hareket seçeneklerinin standart maliyetleri ise Tablo 14'te yer almaktadır.

Tablo 8. Boş Konteyner Hareket Seçeneklerinin Standart Maliyetleri

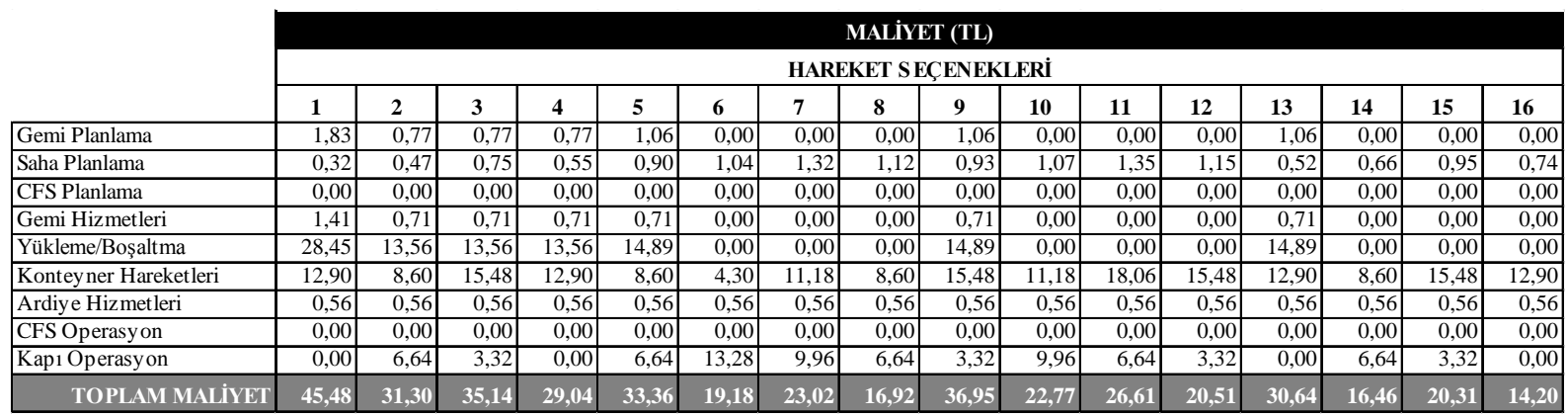

\subsubsection{Transit Konteyner Maliyeti}

Transit konteynerler, limana denizyoluyla giriş yapıp, bir süre limanda muhafaza edildikten sonra başka bir gemiye yüklenerek yine denizyoluyla limanı terk eden dolu konteynerlerdir. $\mathrm{Bu}$ anlamıyla, transit konteynerlerin tek bir hareket seçeneği vardır. Transit konteyner hareketinin standart süresi ve maliyeti Tablo 15’te gösterilmektedir.

Tablo 9. Transit Konteyner Hareketinin Standart Süresi ve Maliyeti

\begin{tabular}{|l|r|r|r|}
\cline { 2 - 4 } \multicolumn{1}{c|}{} & STANDART S ÜRE & KMO & MALIYET (TL) \\
\hline Gemi Planlama & 2,91 & $\mathbf{0 , 6 3}$ & 1,83 \\
\hline Saha Planlama & 0,53 & $\mathbf{0 , 6 1}$ & 0,32 \\
\hline CFS Planlama & 0,00 & $\mathbf{0 , 5 9}$ & 0,00 \\
\hline Gemi Hizmetleri & 0,90 & $\mathbf{1 , 5 7}$ & 1,41 \\
\hline Yükleme/Boşaltma & 33,47 & $\mathbf{0 , 8 5}$ & 28,45 \\
\hline Konteyner Hareketleri & 62,00 & $\mathbf{0 , 4 3}$ & 26,66 \\
\hline Ardiye Hizmetleri & 7,00 & $\mathbf{0 , 0 8}$ & 0,56 \\
\hline CFS Operasyon & 0,00 & $\mathbf{2 , 0 1}$ & 0,00 \\
\hline Kap1 Operasyon & 0,00 & $\mathbf{1 , 6 6}$ & 0,00 \\
\hline & \multicolumn{3}{|c|}{ TOPLAM MALIYET (TL) } \\
\hline
\end{tabular}




\subsubsection{Zaman Denklemleri}

$\mathrm{Bu}$ aşamada, tüm konteyner hareket seçeneklerini kapsayacak şekilde, her bir kaynak grubuna ilişkin zaman denklemleri oluşturulmuştur. Böylece, hareket yönü ve dolu ya da boş olması gibi bir ayrım yapılmaksızın, bir konteyner için gerçekleştirilen faaliyetlerin sürelerini kaynak grubu bazında belirlemek mümkün olmaktadır. Ayrıca, daha önce maliyetleri standart süreler doğrultusunda hesaplanan tüm hareket seçeneklerinin süre ve maliyetleri, standart diş1 faaliyetlerin de kolaylıkla sürece dâhil edilebildiği bir şekilde hesaplanabilmektedir.

\subsection{5..1. Gemi Planlama Kaynak Grubu Süreç Zamanı}

Gemi planlama sürecinin standart süresi konteyner başına 0,56 dk'dır. Standart sürenin üzerine, eğer konteyner gemiye yüklenmişse $1,13 \mathrm{dk}$, eğer gemiden boşaltılmışsa $0,66 \mathrm{dk}$ eklenmesi gerekmektedir. Eğer geminin limana ilk kez gelişiyse, bu sürelerin üzerine, 0,02 dk daha eklenmesi gerekmektedir. Bu veriler doğrultusunda, gemi planlama süreç zamanı aşağıdaki şekilde formülleştirilmektedir:

Gemi Planlama Kaynak Grubu Süreç Zamanı = EĞER(yükleme>0;1,69;0) + EĞER(boşaltma $>0 ; 1,22 ; 0)+$ EĞER(geminin gelme sayısı $<1 ; 0,02 ; 0)$

\subsubsection{Saha Planlama Kaynak Grubu Süreç Zamanı}

Saha planlama sürecinde, eğer konteyner gemiye yüklenmişse $0,24 \mathrm{dk}$, eğer gemiden boşaltılmışsa 0,29 dk'lık planlama faaliyeti gerçekleştirilmektedir. Karayoluyla araç kapıdan giriş yapan konteyner için $1,23 \mathrm{dk}$, çıkış yapan konteyner için $0,48 \mathrm{dk}$ planlama faaliyeti gerçekleştirilirken; demiryoluyla vagon kapıdan giriş yapan konteyner için 1,28 dk, çıkış yapan konteyner için ise $0,94 \mathrm{dk}$ gerekmektedir. İç dolum ya da iç boşaltım için konteynerin CFS sahasına gitmesi durumunda, istif sahasıyla CFS sahası arasındaki hareketin planlanmas1 0,61 dk sürmektedir. Bunların dışındaki olası diğer hareketlerin saha planlaması için, hareket başına $0,31 \mathrm{dk}$ gerekmektedir. Bu veriler doğrultusunda, saha planlama süreç zamanı aşağıdaki şekilde formülleştirilmektedir:

Saha Planlama Kaynak Grubu Süreç Zamanı = EĞER(yükleme>0;0,24;0) + EĞER(boşaltma $>0 ; 0,29 ; 0)+$ EĞER(araç kap1 giriş>0;1,23;0) + EĞER(vagon kap1 giriş>0;1,28;0) + EĞER(araç kapı çıkış>0;0,48;0) + EĞER(vagon kapı çıkış>0;0,94;0) + EĞER(iç dolum $>0 ; 0,61 ; 0)+$ EĞER(iç boşaltım $>0 ; 0,90 ; 0)+(0,31$ x diğer hareket sayısı)

\subsubsection{CFS Planlama Kaynak Grubu Süreç Zamanı}

CFS planlaması, eğer konteynere iç dolum yapılmışsa 2,5 dk, eğer iç boşaltım yapılmışsa 7,5 dk sürmektedir. Bu bilgiler doğrultusunda, sürece ilişkin zaman denklemi aşağıdaki şekilde oluşturulmaktadır:

CFS Planlama Kaynak Grubu Süreç Zamanı = EĞER(iç dolum>0;2,5;0) + EĞER(iç boşaltım $>0 ; 7,5 ; 0$ ) 


\subsubsection{Gemi Hizmetleri Kaynak Grubu Süreç Zamanı}

Gemi hizmetleri kaynak grubunda tüm konteynerler için gerçekleştirilen faaliyetler, konteyner başına 0,45 dk sürmektedir. Eğer gemiye tatlı su verilmişse, 0,03 dk; katı atıkları alınmışsa, 0,07 dk; sıvı atıkları alınmışsa, 0,41 dk ek süre oluşmaktadır. Bu veriler doğrultusunda, sürece ilişkin zaman denklemi aşağıdaki şekilde oluşturulmaktadır:

Gemi Hizmetleri Kaynak Grubu Süreç Zamanı:

$(0,45$ x yükleme/boşaltma sayısı $)+$ EĞER(tatlı su>0;0,03;0) + EĞER(katı atık $>0 ; 0,07 ; 0)+$ EĞER(sıvı atık $>0 ; 0,41 ; 0)$

\subsubsection{Yükleme/Boşaltma Kaynak Grubu Süreç Zamanı}

Yükleme/boşaltma kaynak grubunda tüm konteynerler için gerçekleştirilen faaliyetlerin toplam süresi $0,38 \mathrm{dk}$ 'dır. Yalnızca yüklenen konteynerler için gerçekleştirilen faaliyetler toplam 17,14 dk sürmektedir. Buna karşılık, yalnızca boşaltılan konteynerler için gerçekleştirilen faaliyetlerin toplam süresi $15,57 \mathrm{dk}$ 'dır. Bu durumda, yüklemesi yapılan bir konteynerin yükleme/boşaltma süreç zamanı 17,52 dk, boşaltması yapılan bir konteynerin yükleme/boşaltma süreç zamanı ise 15,95 dk olmaktadır. Eğer açılan ambar kapakları rıhtıma indirilmeyip gemi üzerinde bırakılırsa, bu süreden $0,18 \mathrm{dk}$ düşülmesi gerekmektedir. Konteynerin yüklemesi Gantry vinçle değil de mobil vinçle yapılırsa, 2,5 dk ek süre gerekmektedir. Boşaltmanın mobil vinçle yapılmasının süreç zamanına bir etkisi yoktur. 20' konteynerde ekstra pabuç kullanılması durumunda, pabuçların takılması için $2 \mathrm{dk}$, sökülmesi için $1 \mathrm{dk}$ ek süre oluşmaktadır. Gemi-içi shifting olarak adlandırılan, konteynerin gemide yerinin değiştirilmesi faaliyeti, $8 \mathrm{dk}$ sürmektedir. Konteynerin yüklenmesi ya da boşaltılması için sapanlama yapılması durumunda $60 \mathrm{dk}$, spreader'e ekstra parça takılması durumunda ise 120 dk ek süre oluşmaktadır. Bu veriler doğrultusunda, yükleme/boşaltma kaynak grubunun zaman denklemi aşağıdaki şekilde oluşturulmaktadır:

Yükleme/Boşaltma Kaynak Grubu Süreç Zamanı = EĞER(yükleme>0;17,52;0) + EĞER(boşaltma $>0 ; 15,95 ; 0)$ - EĞER(ambar kapakları gemi üzerinde $>0 ; 0,18 ; 0)+$ EĞER(20' ekstra pabuç takma>0;2;0) + EĞER(20' ekstra pabuç sökme>0;1;0)+ EĞER(mobil vinçle yükleme $>0 ; 2,5 ; 0)+(8$ x gemi-içi shifting sayıs1 $)+$ EĞER(spreader parça değişim $>0 ; 120 ; 0)+$ EĞER(sapanlama>0;60;0)

\subsubsection{Konteyner Hareketleri Kaynak Grubu Süreç Zamanı}

Konteynerlerin istife konması ve istiften alınmasında iki çeşit vinç kullanılabilmektedir. Bunlar RTG ve Reachstacker'dır. Standart süre hesaplamalarında, dolu konteynerlerin RTG ile istiflendiği ve istiften alındığ 1 varsayılmıştır. Bu varsayım altında, dolu bir konteynerin istife konması ve istiften alınması faaliyetleri $8 \mathrm{dk}$ sürmektedir. $\mathrm{Bu}$ faaliyetlerin Reachstacker ile yapılması durumunda ise süre 2'şer dk azalmaktadır. Boş konteynerin istife konması ve istiften alınması faaliyetleri, 5'er dk sürmektedir. Demiryoluyla limana giriş yapan konteynerlerin vagondan indirilmesi, demiryoluyla limandan çıkış yapan 
konteynerlerin ise vagona yüklenmesi faaliyetleri Reachstacker ile gerçekleştirilmekte ve $6 \mathrm{dk}$ ek süre oluşturmaktadır. Konteynerin; kantar hariç diğer terminal sahaları arasında (rıhtım, istif sahaları, CFS sahası, vagon sahası, ambar önü vb.) gerçekleşen hareketleri 10'ar dk; istif sahalarıyla kantar arasındaki hareketi ise $15 \mathrm{dk}$ sürmektedir. Dolayısıyla, kantar sahasına olan hareket, terminal sahaları arasında oluşabilecek diğer hareketlerden $5 \mathrm{dk}$ daha fazla ek süre gerektirmektedir. Eğer konteynerin kaldırılabilmesi için sapanlama yapılması gerekiyorsa, yapılan her sapanlama için süreç zamanı $60 \mathrm{dk}$ uzamaktadır. Bu veriler doğrultusunda, konteyner hareketleri kaynak grubu süreç zamanı aşağıdaki şekilde formülleştirilmektedir.

Konteyner Hareketleri Kaynak Grubu Süreç Zamanı $=(8 \mathrm{x}$ dolu konteyneri istife koyma sayıs1 $)+(8 \times$ dolu konteyneri istiften alma sayıs1) - (2 x Reachstacker ile istife koyma sayıs1) - (2x Reachstacker ile istiften alma sayısı) $+(5 \mathrm{x}$ boş konteyneri istife koyma sayısı) $+(5 \mathrm{x}$ boş konteyneri istiften alma sayısı $)+(10 \mathrm{x}$ sahalar arası transfer sayısı $)+$ EĞER(kantar>0;5;0) + EĞER(vagon kapı giriş>0;6;0) + EĞER(vagon kapı çıkış>0;6;0) + (60 $\mathrm{x}$ sapanlama sayıs1)

\subsubsection{Ardiye Hizmetleri Kaynak Grubu Süreç Zamanı}

Ardiye hizmetleri kaynak grubunun süreç zamanı, dolu ya da boş konteynerin limanda muhafaza edildiği süreye eşittir ve aşağıdaki şekilde formülleştirilmektedir:

Ardiye Hizmetleri Süreç Zamanı = Konteynerin limanda kaldığı gün sayısı

\subsubsection{CFS Operasyon Kaynak Grubu Süreç Zamanı}

CFS operasyon kaynak grubunun standart süresi hesaplanırken, iç dolum ve iç boşaltım işlemlerinin forkliftle yapıldığı varsayılmıştır. 20' konteyner için iç boşaltım faaliyetleri toplam $53 \mathrm{dk}$, iç dolum faaliyetleri ise toplam $63 \mathrm{dk}$ sürmektedir. İç dolumun ve iç boşaltımın insan gücüyle yapılması durumunda, standart süreye $50 \mathrm{dk}$ ekleme yapılması gerekmektedir. 40' konteynerin iç boşaltımı toplam $93 \mathrm{dk}$, iç dolumu ise toplam $108 \mathrm{dk}$ olarak gerçekleşmektedir. 40' konteynerin iç dolumunun ve iç boşaltımının insan gücüyle yapılması durumunda ise, bu sürelere $100 \mathrm{dk}$ daha eklenmesi gerekmektedir. $\mathrm{Bu}$ veriler doğrultusunda, CFS operasyon kaynak grubu süreç zamanı aşağıdaki şekilde formülleştirilmektedir:

CFS Operasyon Kaynak Grubu Süreç Zamanı = EĞER(20' konteyner iç boşaltım $>0 ; 53 ; 0)+\operatorname{EĞER}\left(40^{\prime}\right.$ konteyner iç boşaltım $\left.>0 ; 93 ; 0\right)+\operatorname{EĞER}\left(20^{\prime}\right.$ konteyner iç dolum $>0 ; 63 ; 0)+$ EĞER(40' konteyner iç dolum $>0 ; 108 ; 0)+\operatorname{EĞER(20'~konteyner~insan~}$ gücüyle iç boşaltım ve iç dolum $>0 ; 50 ; 0)+$ EĞER(40' konteyner insan gücüyle iç boşaltım ve iç dolum $>0 ; 100 ; 0$ )

\subsubsection{Kapı Operasyon Kaynak Grubu Süreç Zamanı}

Araç kapıdan giriş ya da çıkış yapan bir konteynerin kapı operasyon faaliyetleri $4 \mathrm{dk}$ sürerken, vagon kapıdan giriş ya da çıkış yapan bir konteynerin kapı operasyon faaliyetleri 2 $\mathrm{dk}$ sürmektedir. $\mathrm{Bu}$ veriler doğrultusunda, zaman denklemi aşağıdaki şekilde 
oluşturulmaktadır: Kap1 Operasyon Kaynak Grubu Süreç Zamanı = EĞER(araç kapı giriş>0;4;0) + EĞER(araç kapı çıkış>0;4;0) + EĞER(vagon kapı giriş>0;2;0) + EĞER(vagon kapı çıkış>0;2;0)

\subsection{Uygulama Sonuçlarının Değerlendirilmesi}

$\mathrm{Bu}$ çalışmada, İzmir Alsancak Limanı konteyner terminalinde gerçekleşen fiili maliyet verilerinden faydalanılarak, bir yıl içerisinde terminalden hizmet alan "bir konteyner"in maliyeti ZEFTM yöntemiyle hesaplanmıştır. Terminalden hizmet alan konteynerlerin farklı yollar izlemeleri ve farklı faaliyetleri tüketmeleri mümkündür. Bu nedenle konteynerler; kara yönünde hareket eden dolu konteynerler, deniz yönünde hareket eden dolu konteynerler, boş konteynerler ve transit konteynerler olmak üzere dört ana gruba ayrılmış, bu gruplar dâhilinde oluşabilecek farklı hareket kombinasyonlarının maliyetleri ayrı ayrı belirlenmiştir.

Geleneksel FTM sistemlerinde, yalnızca faaliyetlerin tüketim miktarları dikkate alınmakta; birbirine çok benzeyen ve aynı maliyet havuzunda yer alan faaliyetlerin, farklı hareket seçeneklerinde farklı sürelerde gerçekleştirilebileceği, dolayısıyla da farklı maliyetler oluşturabileceği gerçeği göz ardı edilmektedir. ZEFTM sistemleri, FTM'den farklı olarak, faaliyetlerin gerçekleştirilme sürelerini temel almaktadır. Örneğin, bir konteynerin gemiye yüklenmesi faaliyeti ile gemiden boşaltılması faaliyeti birbiriyle özdeş gözükmektedir. Tek fark, birinde hareketin rıhtımdan gemiye doğru; diğerinde ise, gemiden rıhtıma doğru yapılmasıdır. FTM sistemi, bu iki faaliyeti aynı olarak görmekte ve bu faaliyetleri tüketen konteynerlere eşit tutarda maliyet yüklemektedir. Ancak, faaliyetlerin gerçekleştirilme süreleri dikkate alındığında durum farklılaşmakta; aynı gibi gözüken bu iki faaliyetin aslında çok da özdeş olmadıkları ortaya çıkmaktadır. Bir konteynerin gemiye yüklenmesi, gemiden boşaltılmasından daha uzun sürmektedir. Bu nedenle, maliyetlerin dağıtımında faaliyetlerin gerçekleştirilme sürelerini baz alan ZEFTM'de, gemiye yüklenen bir konteynerin maliyeti, gemiden boşaltılan bir konteynerin maliyetinden daha yüksek tutarda oluşmaktadır. Benzer şekilde, gemiye yüklenecek bir konteynerin limanda iç dolumunun yapılması, gemiden boşaltılan bir konteynerin limanda iç boşaltımının yapılmasından daha uzun sürmekte; bu da, konteynerin yönüne göre, CFS operasyonlarının maliyetini değiştirmektedir.

Ayrıca, FTM'de, standart dişı faaliyetlerin maliyetleri maliyet havuzundaki tüm konteynerlere paylaştırılırken; ZEFTM'de, yalnızca o faaliyeti tüketen konteynerlere yüklenmektedir. ZEFTM sistemlerinin en önemli avantajlarından bir diğeri, kullanılmayan (atıl) kapasiteyi görünür kılmasıdır. Kaynak grupları bazında daha önce hesaplanmış olan pratik ve fiili kapasiteler ile kapasite kullanım oranları ve kullanılmayan kapasite oranları, Tablo 16'da gösterilmektedir. Kapasite kullanım oranı (KKO), fiili kapasitenin pratik kapasiteye oranı olup, kaynak gruplarına tahsis edilen kaynakların hangi seviyede kullanıldıklarını göstermektedir. Görüldüğü gibi gemi hizmetleri, \%74,44 kullanılmayan kapasite oranıyla, kaynaklarını en verimsiz kullanan kaynak grubudur. Buna karşılık kapı 
operasyon kaynak grubu, \%115 kapasite kullanım oranıyla, pratik kapasitesinin üzerinde faaliyet göstermektedir.

Tablo 10. Kaynak Gruplarının Kapasite Kullanım Oranları

\begin{tabular}{|lr|r|c|c|}
\hline KAYNAK GRUBU & Pratik Kapasite & Fiili Kapasite & KKO (\%) & $\begin{array}{c}\text { Kullanılmayan } \\
\text { Kapasite (\%) }\end{array}$ \\
\hline Gemi Planlama & 815.507 & $733.572,00$ & 89,95 & 10,05 \\
\hline Saha Planlama & $937.571,25$ & $600.210,00$ & 64,02 & 35,98 \\
\hline CFS Planlama & $242.492,25$ & $176.545,00$ & 72,80 & 27,20 \\
\hline Gemi Hizmetleri & $1.477 .947,75$ & $377.692,00$ & 25,56 & 74,44 \\
\hline Yükleme/Boşaltma & 27.764 .597 & $9.233 .617,71$ & 33,26 & 66,74 \\
\hline Konteyner Hareketleri & $60.149 .415,10$ & $18.753 .165,26$ & 31,18 & 68,82 \\
\hline Ardiye Hizmetleri & $15.280,00$ & $12.773,00$ & 83,59 & 16,41 \\
\hline CFS Operasyon & $3.570 .613,38$ & $2.738 .848,00$ & 76,71 & 23,29 \\
\hline Kap1 Operasyon & 1.396 .125 & $1.609 .614,00$ & 115,29 & $-15,29$ \\
\hline
\end{tabular}

Kullanılmayan kapasite maliyetleri, ZEFTM'de konteyner maliyetine dâhil edilmemektedir. Bu sayede ZEFTM sistemleri, daha doğru ve gerçekçi maliyet tutarları ortaya koyarken, kaynak gruplarının verimliliğine ilişkin önemli ipuçları da sağlamaktadır. Kullanılan ve kullanılmayan kapasitelerin maliyetleri Tablo 17'de yer almaktadır.

Tablo 11. Kaynak Gruplarının Kullanılan ve Kullanılmayan Kapasite Maliyetleri

\begin{tabular}{|l|r|r|r|}
\hline KAYNAK GRUBU & $\begin{array}{r}\text { Kullanılan Kapasite } \\
\text { Maliyeti }\end{array}$ & $\begin{array}{c}\text { Kullanılmayan } \\
\text { Kapasite Maliyeti }\end{array}$ & Toplam Maliyet \\
\hline Gemi Planlama & $462.150,36$ & $50.196,76$ & $512.347,12$ \\
\hline Saha Planlama & $365.934,16$ & $205.681,36$ & $571.615,52$ \\
\hline CFS Planlama & $104.040,30$ & $38.863,58$ & $142.903,88$ \\
\hline Gemi Hizmetleri & $591.165,12$ & $1.722 .124,97$ & $2.313 .290,09$ \\
\hline Yükleme/Boşaltma & $7.848 .575,06$ & $15.737 .619,60$ & $23.586 .194,66$ \\
\hline Konteyner Hareketleri & $8.063 .861,06$ & $17.913 .307,89$ & $25.977 .168,95$ \\
\hline Ardiye Hizmetleri & $356.019,61$ & $69.875,90$ & $425.895,51$ \\
\hline CFS Operasyon & $5.497 .241,13$ & $1.669 .466,45$ & $7.166 .707,58$ \\
\hline Kap1 Operasyon & $2.671 .547,59$ & $-354.337,14$ & $2.317 .210,45$ \\
\hline TOPLAM & $\mathbf{2 5 . 9 6 0 . 5 3 4 , 3 9}$ & $\mathbf{3 7 . 0 5 2 . 7 9 9 , 3 7}$ & $\mathbf{6 3 . 0 1 3 . 3 3 3 , 7 7}$ \\
\hline
\end{tabular}

Ayrıca, kaynak grubu bazında belirlenen zaman denklemleri sayesinde, birbirinden farklı hizmetler talep eden tüm konteynerler için gerçekleştirilen faaliyetlerin maliyetleri kolaylıkla ve doğru bir şekilde hesaplanabilmektedir.

\section{SONUÇ}

Bir geminin limanda kaldığı süreyi ifade eden “döngü zamanı”, konteyner terminalleri için önemli bir performans ölçütüdür. Döngü zamanını azaltmak, terminalde gerçekleştirilen faaliyetlerin verimini, yani kapasite kullanımını artırmakla mümkün olabilir. Verimin artırılması ise tüm terminal faaliyetlerinin en hızlı şekilde gerçekleşmesini sağlamakla 
mümkündür. Dolayısıyla, konteyner terminallerinde "zaman", belirleyici bir kapasite ölçütü olmaktadir.

Ayrıca, konteyner terminallerinde kullanılan ekipmanın yüksek satın alma maliyetleri ve konteyner terminallerinin yüksek işletim maliyetleri, limanları daha verimli çalışmak yönünde zorlamaktadır. Öte yandan, geminin, hareket halindeyken para kazandıran bir araç olması dolayısıyla, gemi işletmecileri gemilerin limanda olabildiğince kısa süre kalmalarını tercih etmektedirler. Gemilerin limanda daha kısa süre kalmaları, yalnızca limana verilen ücretin azalması anlamına gelmemekte; aynı zamanda, taşıma için daha az gemiye ihtiyaç duyulması sonucunu da doğurmaktadır. Bu koşullar altında “zaman”, konteyner terminal işletmeciliğinde önemli bir rekabet unsuru olmaktadır.

Faaliyetlerin gerçekleştirilme sürelerinin performans ve başarı ölçütü olarak görüldüğü konteyner terminali işletmeciliği sektöründe, zamanı temel alan bir maliyetleme sistemi, daha anlamlı sonuçlar vermektedir. ZEFTM; strateji, operasyonlar ve maliyetler arasındaki bağlantıyı sağlayarak kapasite yönetimini destekleyen bir sistemdir. Faaliyetlerin sürelerinde yapılan iyileştirmelerin maliyetler üzerindeki etkisi, ZEFTM sisteminde hemen görülebilmektedir. Benzer şekilde, optimizasyon yöntemlerinin sonuçları da ZEFTM sisteminde hemen maliyetlere yansit1labilmekte, kaynak gruplarının kapasite kullanım oranlarına etkisi hemen belirlenebilmektedir. ZEFTM'nin daha doğru maliyet bilgisi üretmesi ve kapasite analizlerinin yapılabilmesine olanak sağlaması, yöntemin karar alma mekanizmasına büyük faydalar sağladığını göstermektedir.

Bu çalışmanın kısıtları, esas olarak uygulamanın bir devlet işletmesinde yapılmasından kaynaklanmaktadır. Limanda bir maliyet muhasebesi sisteminin uygulanmaması, yüklü miktarda ham verinin analiz edilmesini gerektirmiştir. $\mathrm{Bu}$ süreçte, bazı memurların kadrolarının olduğu yerde değil başka birimlerde çalıştıkları ya da bazı işçilerin birden çok birimde çalıştıkları görülmüştür. Hesaplamalar yapılırken, memurlar fiilen çalıştıkları birimlere dâhil edilmiş, birden çok birimde çalışan işçilerin işçilik saatleri, yapılan görüşmelerden elde edilen bilgiler doğrultusunda bölünmüş ve olabildiğince doğru sonuçlar elde edilmeye çalışılmıştır. Bir başka kısıt, faaliyet sürelerinin belirlenmesinde kendini göstermiştir. Faaliyet süreleri, gemilerin durağan olmadıkları gerçeği göz önünde bulundurularak değerlendirilmelidir. Hava ve deniz koşulları, faaliyetlerin sürelerini etkileyebilmektedir. Tüm bu kısıtlara rağmen, bu çalışmanın, önceki çalışmalarda yer almayan bir sektör olan konteyner terminali işletmeciliği sektörüne odaklanmasıyla ve zaman denklemleri kullanılarak işletmenin hizmet üretim maliyetlerine ilişkin bir model ortaya koymasıyla literatüre katkı sağlayacağı düşünülmektedir. 


\section{KAYNAKLAR}

Atkinson, Anthony (2007), “Fixed Factor Fine Tuning”, CMA Management, 81(7), ss. 42-46.

Atmaca, Metin - Terzi, Serkan (2007), "Zaman Etkenli Faaliyet Tabanlı Maliyetleme", Karamanoğlu Mehmetbey Üniversitesi Sosyal ve Ekonomik Araştırmalar Dergisi, 2, ss. 367-384.

Berikol, B. Zafer - Güner, M. Fatih (2016), "Faaliyet Tabanlı Maliyetleme ve Süreye Dayalı Faaliyet Tabanlı Maliyetleme Yöntemleri”, Selçuk Teknik Online Dergi, ss. 10761087.

Cengiz, Emre (2011), "Faaliyet Tabanlı Maliyetleme ve Sürece Dayalı Faaliyet Tabanlı Maliyetleme Arasındaki Farklar - Bir Mobilya Üreticisi Firmada Vaka Çalışması”, Muhasebe ve Finansman Dergisi, 50, ss. 33-58.

Cokins, Gary (1999), “Learning to Love ABC”, Journal of Accountancy, 188(2), ss. 37-39.

Cooper, Robin - Kaplan, Robert S. (1990), “Measure Costs Right: Make the Right Decisions”, The CPA Journal, 60(2), ss. 38-45.

Dalcı, İlhan - Tanış, Veyis - Koşan, Levent (2010), “Customer Profitability Analysis with Time-Driven Activity-Based Costing: A Case Study in a Hotel”, International Journal of Contemporary Hospitality Management, 22(5), ss. 609-637.

Daly, John L. (2002), Pricing for Profitability: Activity-Based Pricing for Competitive Advantage, John Wiley \& Sons, Inc., New York.

Everaert, Patricia - Bruggeman, Werner (2007), “Time-Driven Activity-Based Costing: Exploring the Underlying Model”, Cost Management, 21(2), ss. 16-20.

Fennema, M. G. - Rich, Jay S. - Krumwiede, Kip (2005), “Asymmetric Effects of ActivityBased Costing System Cost Reallocation”, Advances in Accounting Behavioral Research, 8, ss. 167-187.

Geri, Nitza - Ronen, Boaz (2005), "Relevance Lost: The Rise and Fall of Activity-Based Costing”, Human Systems Management, 24(2), ss. 133-144.

Gervais, Michel - Levant, Yves - Ducrocq, Charles (2010), “Time-Driven Activity-Based Costing (TDABC): An Initial Appraisal through a Longitudinal Case Study”, Journal of Applied Management Accounting Research, 8(2), ss. 1-20.

Gosselin, Maurice (2007), “A Review of Activity-Based Costing: Technique, Implementation, and Consequences”, Handbooks of Management Accounting Research, 2, ss. 641-671.

Gunasekaran, Angappa - Sarhadi, Mansoor (1998), "Implementation of Activity-Based Costing in Manufacturing”, International Journal of Production Economics, 56-57(1), ss. 231-242.

Hoozee, Sophie - Vermeire, Lea - Bruggeman, Werner (2009), “A Risk Analysis Approach for Time Equation-Based Costing”, Working Paper. Universiteit Gent, Faculteit Economie en Bedrijfskunde. No. 556. 
Hutchinson, Robert (2007), “Linking Manufacturing Strategy to Product Cost: Toward TimeBased Accounting”, Management Accounting Quarterly, 9(1), ss. 31-42.

Kaplan, Robert S. (1986), “Accounting Lag: The Obsolescence of Cost Accounting Systems”, California Management Review, 28(2), ss. 174-199.

Kaplan, Robert S. - Anderson, Steven R. (2007a), Time-Driven Activity-Based Costing: A Simpler and More Powerful Path to Higher Profits, Boston: Harvard Business School Press.

Kaplan, Robert S. - Anderson, Steven R. (2007b), “The Innovation of Time-Driven ActivityBased Costing”, Cost Management, 21(2), ss. 5-15.

Kaplan, Robert S. - Anderson, Steven R. (2007c), “The Speed-Reading Organization”, Business Finance, 13(6), ss. 39-42.

Kırlıoğlu, Hilmi - Atalay, Bedia (2014), "Hastane İşletmelerinde Sürece Dayalı Faaliyet Tabanlı Maliyetleme Modellemesi”, Dumlupınar Üniversitesi Sosyal Bilimler Dergisi, 41, ss. 141-161.

Labro, Eva (2006), “Analytics of Costing System Design”, Bhimani, A. (Ed.), Contemporary Issues in Management Accounting, Oxford University Press, Oxford, ss. 217-242.

Öker, Figen - Adıgüzel, Hümeyra (2010), “Time-Driven Activity-Based Costing: An Implementation in a Manufacturing Company”, Journal of Corporate Accounting \& Finance, 22(1), ss. 75-92.

Polat, Levent (2011), “Zaman Sürücülü Faaliyet Tabanlı Maliyetlemenin Bir Sanayi İşletmesinde Uygulanması”, Muhasebe ve Finansman Dergisi, 49, ss. 126-137.

Pryor, Tom (2010), “A Financial Thermometer for Lean Operations”, The Journal of Corporate Accounting \& Finance, 21(2), ss. 81-91.

Saban, Metin - İrak, Gülay G. (2009), "Çağdaş Maliyet Yönetimi Sistemlerinden Sürece Dayalı Faaliyet Tabanlı Maliyetleme”, Zonguldak Karaelmas Üniversitesi Sosyal Bilimler Dergisi, 5(10), ss. 97-108.

Steenken, Dirk - Voß, Stefan - Stahlbock, Robert (2004), “Container Terminal Operation and Operations Research - A Classification and Literature Review”, OR Spectrum, 26(1), ss. 3-49.

Stevenson, Thomas H. - Barnes, Frank C. - Stevenson, Sharon A. (1996), “Activity-Based Costing: Beyond the Smoke and Mirrors”, Review of Business. 18(1), ss. 25-31.

Wang, Teng-Fei - Cullinane, Kevin - Song, Dong-Wook (2005), Container Port Production and Economic Efficiency, Palgrave Macmillan, New York.

Wegmann, Gregory (2009), “The Activity-Based Costing Method: Developments and Applications”, The IUP Journal of Accounting Research and Audit Practices, 8(1), ss. 7-22.

Y1lmaz, Rifat (2008), “Creating the Profit Focused Organization Using Time-Driven Activity Based Costing”, EABR \& TLC Conferences Proceedings, Salzburg, Avusturya. 
Yükçü, Süleyman - Gönen, Seçkin (2009), “Zaman Esaslı Faaliyete Dayalı Maliyetleme Yaklaşımının Otomobil Parçaları Üreten Bir İşletmede Uygulanması”, Muhasebe ve Denetime Bak1ş, 28, ss. 19-31.

Zimmerman, Jerrold L. (2011), Accounting for Decision Making and Control, McGraw-Hill, New York. 